Check for updates

Cite this: RSC Adv., 2019, 9, 17025

Received 7th April 2019

Accepted 23rd April 2019

DOI: 10.1039/c9ra02597a

rsc.li/rsc-advances

\title{
UPLC-MS-guided isolation of single ether linkage dimeric 2-(2-phenylethyl)chromones from Aquilaria sinensis $\dagger$
}

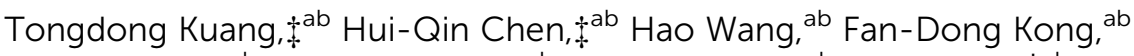 \\ Cai-Hong Cai, ${ }^{\text {ab }}$ Wen-Hua Dong, ${ }^{\text {ab }}$ Jing-Zhe Yuan, ${ }^{\text {ab }}$ Wen-Li Mei ${ }^{\star a b}$ \\ and Hao-Fu Dai (D) *ab
}

\begin{abstract}
Eleven novel uncommon single ether linkage dimeric 2-(2-phenylethyl)chromones (aquilasinenones A-K) were isolated by a UPLC-MS guided method from artificial hole-induced agarwood originating from Aquilaria sinensis. Their structures were unambiguously deduced using HRESIMS data, detailed $1 D$ and 2D NMR spectroscopic analysis, and experimental ECD spectra. All the compounds were tested for acetylcholinesterase (AChE) inhibitory activity by Ellman's colorimetric method, and compounds 9-11 displayed weak AChE inhibitory activity with the inhibition ranging from $15.6 \%$ to $16.8 \%$ at a concentration of $50 \mu \mathrm{g} \mathrm{mL}^{-1}$.
\end{abstract}

\section{Introduction}

Agarwood, widely used in perfumes, incenses, and traditional medicine, is an aromatic dark resin produced by the heartwood of the Aquilaria and Gyrinops species of the Thymelaeaceae family when suffering from a natural or artificial injury. ${ }^{1-3}$ Aquilaria sinensis (Lour.), which is distributed in southern China, is a peculiar plant resource of Chinese agarwood. ${ }^{4}$

2-(2-Phenylethyl)chromones are characterized as a group of uncommon chromones possessing a phenylethyl substituent at $\mathrm{C}-2$ and have been reported to be one of the main diagnostic constituents of agarwood. ${ }^{5,6}$ Interestingly, 2-(2-phenylethyl) chromone dimers and trimers have been derived from agarwood recently; even though the first batch from Kalimantan agarwood was reported by Siu Kiyosawa's group, ${ }^{7-11}$ the process could not be traced until the analogues were rediscovered again in 2017. ${ }^{12-16}$ These distinctive structures originating from agarwood showed diverse linkages between the subunits via carboncarbon bonds and/or ether bonds. However, not more than twenty structures featuring a single ether linkage between the 5,6,7,8-tetrahydro-2-(2-phenylethyl)chromone and 2-(2-phenylethyl)chromone units have been reported since the first one was found, ${ }^{3,16}$ and they exhibited various biological activities

${ }^{a}$ Hainan Engineering Research Center of Agarwood, Institute of Tropical Bioscience and Biotechnology, Chinese Academy of Tropical Agricultural Sciences, Haikou 571101, PR China.E-mail:meiwenli@itbb.org.cn; daihaofu@itbb.org.cn

${ }^{b}$ Hainan Key Laboratory for Research and Development of Natural Products from $L i$ Folk Medicine, Institute of Tropical Bioscience and Biotechnology, Chinese Academy of Tropical Agricultural Sciences, Haikou 571101, PR China

$\dagger$ Electronic supplementary information (ESI) available. See DOI: 10.1039/c9ra02597a

$\ddagger$ These authors contributed equally to this work. including acetylcholinesterase (AChE) inhibition, antineuroinflammatory action, and cytotoxicity in pharmacological researches. $^{7-16}$

Previous phytochemical studies on the chemical constituents of artificial hole-induced agarwood originating from $A$. sinensis contributed to the identification of a series of sesquiterpenes $^{17}$ and 2-(2-phenylethyl)chromone derivatives, ${ }^{18-20}$ including four 2-(2-phenylethyl)chromone dimers. ${ }^{13}$ Herein, the ongoing studies targeted the distinct characterization of the 5,6,7,8-tetrahydro-2-(2-phenylethyl)chromone and 2-(2-phenylethyl)chromone dimer derivatives guided by UPLC-MS, which led to the isolation and elucidation of eleven 2-(2-phenylethyl) chromone dimers with an ether linkage, as well as the identification of their absolute configurations. All the dimers were tested for acetylcholinesterase (AChE) inhibitory activity by Ellman's colorimetric method, and compounds 9-11 displayed weak AChE inhibitory activity with inhibitions in the range of $15.6-16.8 \%$ at a concentration of $50 \mu \mathrm{g} \mathrm{mL} \mathrm{m}^{-1}$.

\section{Results and discussion}

Aquilasinenone A (1) was obtained as a yellow oil. Its molecular formula was established as $\mathrm{C}_{37} \mathrm{H}_{36} \mathrm{O}_{13}$ based on the HRESIMS pseudomolecular ion peak at $m / z 711.2057[\mathrm{M}+\mathrm{Na}]^{+}$(calcd for $\mathrm{C}_{37} \mathrm{H}_{36} \mathrm{NaO}_{13}, 711.2048$ ). The ${ }^{1} \mathrm{H}$ NMR spectrum (Table 1) displayed three methoxy groups, two singlet olefinic protons, and two sets of ABX coupling aromatic systems, along with four methylenes and four oxygenated methines. The ${ }^{13} \mathrm{C} N M R$ spectrum (Table 2) presented two carbonyl groups, twenty-four olefinic carbons, four oxygenated tertiary carbons, three methoxyl carbons, and four secondary carbons. The above data hinted a dimeric 2-(2-phenylethyl)chromone derivative 
comprising 5,6,7,8-tetrahydro-2-(2-phenylethyl)chromone (unit A) and 2-(2-phenylethyl)chromone (unit B) moieties.

The structure of unit A was deduced to be the same as that of aquilarone $\mathrm{A}^{\mathbf{2 1}}$ on the basis of $1 \mathrm{D}$ and $2 \mathrm{D}$ NMR data. The tetrahydrochromone fragment was concluded by the respective signals of a pyrone fragment $\left[\delta_{\mathrm{C}} 171.3(\mathrm{C}-2), \delta_{\mathrm{C}} 114.5 / \delta_{\mathrm{H}} 6.13\right.$ $\left.(1 \mathrm{H}, \mathrm{s}, \mathrm{H}-3), \delta_{\mathrm{C}} 181.4(\mathrm{C}-4), \delta_{\mathrm{C}} 162.0(\mathrm{C}-9), \delta_{\mathrm{C}} 122.9(\mathrm{C}-10)\right]$ and four consecutive oxymethines $\left[\delta_{\mathrm{C}} 66.3 / \delta_{\mathrm{H}} 4.83(1 \mathrm{H}, \mathrm{d}, J=3.8 \mathrm{~Hz}\right.$, $\mathrm{H}-5), \delta_{\mathrm{C}} 74.6 / \delta_{\mathrm{H}} 4.14(1 \mathrm{H}, \mathrm{dd}, J=3.8,2.3 \mathrm{~Hz}, \mathrm{H}-6), \delta_{\mathrm{C}} 70.7 / \delta_{\mathrm{H}}$ $4.48(1 \mathrm{H}, \mathrm{dd}, J=7.6,2.3 \mathrm{~Hz}, \mathrm{H}-7)$, and $\delta_{\mathrm{C}} 78.3 / \delta_{\mathrm{H}} 5.63(1 \mathrm{H}, \mathrm{d}, J=$ $7.6 \mathrm{~Hz}, \mathrm{H}-8)]$. The phenylethyl moiety was deduced by the signal for a characteristic $\mathrm{ABX}$ coupling aromatic system $\left[\delta_{\mathrm{C}} 133.8(\mathrm{C}\right.$ $\left.1^{\prime \prime}\right), \delta_{\mathrm{C}} 116.2 / \delta_{\mathrm{H}} 6.46\left(1 \mathrm{H}, \mathrm{d}, J=2.1 \mathrm{~Hz}, \mathrm{H}-2^{\prime \prime}\right), \delta_{\mathrm{C}} 147.6\left(\mathrm{C}-3^{\prime \prime}, 4^{\prime \prime}\right)$, $\delta_{\mathrm{C}} 112.8 / \delta_{\mathrm{H}} 6.67\left(1 \mathrm{H}, \mathrm{d}, J=8.1 \mathrm{~Hz}, \mathrm{H}-5^{\prime \prime}\right), \delta_{\mathrm{C}} 120.2 / \delta_{\mathrm{H}} 6.32(1 \mathrm{H}$, $\left.\left.\mathrm{dd}, J=8.1,2.1 \mathrm{~Hz}, \mathrm{H}-6^{\prime \prime}\right)\right]$ and two methylene groups $\left[\delta_{\mathrm{C}} 32.8 / \delta_{\mathrm{H}}\right.$ $\left.2.52\left(2 \mathrm{H}, \mathrm{m}, \mathrm{H}-7^{\prime \prime}\right), \delta_{\mathrm{C}} 36.6 / \delta_{\mathrm{H}} 2.64\left(2 \mathrm{H}, \mathrm{m}, \mathrm{H}-8^{\prime \prime}\right)\right]$. The methoxyl group $\left(\delta_{\mathrm{C}} 56.4 / \delta_{\mathrm{H}} 3.75\right)$ attached to the aromatic carbon $\mathrm{C}-4^{\prime \prime}$ was confirmed by the HMBC correlation of $\mathrm{OCH}_{3} / \mathrm{C}-4^{\prime \prime}$, as well as the ROESY correlation from $\mathrm{OCH}_{3}$ to $\mathrm{H}-5$ ".

Apart from the aforementioned NMR signals assigned to unit A, the remaining signals indicated a 2-(2-phenylethyl)chromone unit, which showed similarity to 6-methoxy-7-hydroxy-2-[2-(4-methoxyphenyl)ethyl]chromone ${ }^{22}$ with main differences in the substituents on the phenylethyl moiety. The NMR signals $\left[\delta_{\mathrm{C}} 132.8\left(\mathrm{C}-1^{\prime \prime \prime}\right)\right.$, $\delta_{\mathrm{C}} 113.1 / \delta_{\mathrm{H}}\left(6.73,1 \mathrm{H}, \mathrm{d}, J=1.8 \mathrm{~Hz}, \mathrm{H}-2^{\prime \prime \prime}\right), \delta_{\mathrm{C}} 149.9\left(\mathrm{C}-3^{\prime \prime \prime}\right), \delta_{\mathrm{C}} 146.1$ $\left(\mathrm{C}-4^{\prime \prime \prime}\right), \delta_{\mathrm{C}} 116.2 / \delta_{\mathrm{H}}\left(6.65, \mathrm{~d}, J=8.0 \mathrm{~Hz}, \mathrm{H}-5^{\prime \prime \prime}\right), \delta_{\mathrm{C}} 121.8 / \delta_{\mathrm{H}}(6.59, \mathrm{dd}$, $\left.\left.J=8.0,1.8 \mathrm{~Hz}, \mathrm{H}-6^{\prime \prime \prime}\right)\right]$ revealed that an ABX aromatic coupling system existed, and the substituents $4^{\prime \prime \prime}-\mathrm{OH}$ and $3^{\prime \prime \prime}-\mathrm{OCH}_{3}$ were indicated by the downfield chemical shifts of $\mathrm{C}-3^{\prime \prime \prime}$ and $\mathrm{C}-4^{\prime \prime \prime}$, as well as the HMBC correlations from $\mathrm{H}-5^{\prime \prime \prime} / \mathrm{OCH}_{3}\left(\delta_{\mathrm{H}} 3.74\right)$ to $\mathrm{C}-3^{\prime \prime \prime}$ and from $\mathrm{H}-2^{\prime \prime \prime}$ to $\mathrm{C}-4^{\prime \prime \prime}$, and the ROESY correlation of $3^{\prime \prime \prime}-\mathrm{OCH}_{3} / \mathrm{H}-$ $2^{\prime \prime \prime}$. Thus, unit B was assigned as 7-hydroxy-6-methoxy-2-[2-(4'hydroxy-3'-methoxyphenyl)ethyl]chromone.
The presence of the ether linkage $\mathrm{C} 8-\mathrm{O}-\mathrm{C7}^{\prime}$ between units A and $\mathrm{B}$ was determined by the key $\mathrm{HMBC}$ correlation from $\mathrm{H}-8$ to $\mathrm{C}-7^{\prime}$, the ROESY cross-peak of $\mathrm{H}-8 / \mathrm{H}-8^{\prime}$, as well as through the analysis of the molecular formula. The relative configurations of the chiral centers C-5, C- $6, \mathrm{C}-7$ and C-8 were deduced to be the same as those of crassin $\mathrm{D},{ }^{\mathbf{1 4}}$ based on the similar ${ }^{3} \mathrm{~J}_{\mathrm{H}-\mathrm{H}}$ coupling constants for $\mathrm{H}-5 / \mathrm{H}-6(J=3.8 \mathrm{~Hz}), \mathrm{H}-6 / \mathrm{H}-7(J=2.3 \mathrm{~Hz})$ and $\mathrm{H}-7 / \mathrm{H}-8(J=7.6 \mathrm{~Hz})$. The ECD spectrum (Fig. 3) of 1 was opposite to that of crassin $\mathrm{D}$, with a positive Cotton effect around $\lambda_{\max } 280 \mathrm{~nm}$ and a negative Cotton effect around $\lambda_{\max }$ $250 \mathrm{~nm}$, indicating that the front chromophore existed in a clockwise arrangement relative to the rear chromophore, which suggested an $R$ configuration for C-8. Thus, compound 1 was determined to have $(5 S, 6 S, 7 S, 8 R)$-configuration and named as aquilasinenone $\mathrm{A}$.

Aquilasinenone B (2) was obtained as a colorless oil. It possessed the molecular formula $\mathrm{C}_{37} \mathrm{H}_{36} \mathrm{O}_{13}$, as established by HRESIMS. The similarity of its ${ }^{1} \mathrm{H}$ and ${ }^{13} \mathrm{C}$ NMR spectroscopic data (Tables 1 and 2) to those of 1 revealed that they shared structural resemblance except for the substitutions of $3^{\prime \prime \prime}-\mathrm{OH}$ and $4^{\prime \prime \prime}-\mathrm{OCH}_{3}$ on unit $\mathrm{B}$ in 2 . The assignment of $3^{\prime \prime \prime}-\mathrm{OH}$ and $4^{\prime \prime \prime}-$ $\mathrm{OCH}_{3}$ was consistent with the $\mathrm{HMBC}$ correlation from $4^{\prime \prime \prime}-\mathrm{OCH}_{3}$ $\left(\delta_{\mathrm{H}} 3.74\right)$ to $\mathrm{C}-4^{\prime \prime \prime}\left(\delta_{\mathrm{C}} 147.6\right)$, together with the ROESY correlation of $4^{\prime \prime \prime}-\mathrm{OCH}_{3} / \mathrm{H}-5^{\prime \prime \prime}\left(\delta_{\mathrm{H}} 6.71\right)$. The remaining substructures were identical to those of $\mathbf{1}$ based on the detailed analysis of their $2 \mathrm{D}$ NMR spectra (Fig. 2). The configuration of 2 was deduced to be the same as that of $\mathbf{1}$, based on the similar coupling constants of ${ }^{3} J_{5,6}(3.7 \mathrm{~Hz}),{ }^{3} J_{6,7}(2.1 \mathrm{~Hz})$ and ${ }^{3} J_{7,8}(7.6 \mathrm{~Hz})$. Based on the similarity of the ECD curve of 2 to that of 1 , the absolute configuration of 2 could be assigned to be $5 S, 6 S, 7 S$, and $8 R$, and it was given the trivial name of aquilasinenone $\mathrm{B}$.

Aquilasinenone $\mathrm{C}$ (3) was obtained as a yellow oil. Its molecular formula was $\mathrm{C}_{36} \mathrm{H}_{34} \mathrm{O}_{13}$, as indicated by HRESIMS.

Table $1{ }^{1} \mathrm{H}$ NMR spectroscopic data for compounds $1-4(1-3$ at $500 \mathrm{MHz}, 4$ at $600 \mathrm{MHz}, \delta$ in ppm, $\mathrm{J}$ in Hz)

\begin{tabular}{|c|c|c|c|c|c|c|c|c|}
\hline \multirow[b]{2}{*}{ Position } & \multicolumn{2}{|l|}{$\mathbf{1}^{a}$} & \multicolumn{2}{|l|}{$2^{a}$} & \multicolumn{2}{|l|}{$3^{b}$} & \multicolumn{2}{|l|}{$4^{a}$} \\
\hline & Unit A & Unit B & Unit A & Unit B & Unit A & Unit B & Unit A & Unit B \\
\hline $3 / 3^{\prime}$ & $6.13, \mathrm{~s}$ & $6.12, \mathrm{~s}$ & $6.12, \mathrm{~s}$ & $6.10, \mathrm{~s}$ & $6.12, \mathrm{~s}$ & $6.05, \mathrm{~s}$ & $6.14, \mathrm{~s}$ & $6.10, \mathrm{~s}$ \\
\hline $5 / 5^{\prime}$ & $4.83, \mathrm{~d}(3.8)$ & $7.55, \mathrm{~s}$ & $4.82, \mathrm{~d}(3.7)$ & $7.54, \mathrm{~s}$ & $4.58, \mathrm{~d}(3.6)$ & $7.32, \mathrm{~s}$ & $4.82, \mathrm{~d}(3.8)$ & $7.56, \mathrm{~s}$ \\
\hline $6 / 6^{\prime}$ & $4.14, \mathrm{dd}(3.8,2.3)$ & & $\begin{array}{l}4.14, \mathrm{dd} \\
(3.7,2.1)\end{array}$ & & $\begin{array}{l}3.87, \mathrm{dd} \\
(3.6,2.3)\end{array}$ & & 4.14, dd $(3.8,2.3)$ & \\
\hline $7 / 7^{\prime}$ & 4.48, dd $(7.6,2.3)$ & & $\begin{array}{l}4.47, \mathrm{dd} \\
(7.6,2.1)\end{array}$ & & $\begin{array}{l}4.30, \mathrm{dd} \\
(8.0,2.3)\end{array}$ & & 4.47, dd $(7.6,2.3)$ & \\
\hline $8 / 8^{\prime}$ & $5.63, \mathrm{~d}(7.6)$ & $7.60, \mathrm{~s}$ & $5.64, \mathrm{~d}(7.6)$ & $7.58, \mathrm{~s}$ & $5.39, \mathrm{~d}(8.0)$ & $7.55, \mathrm{~s}$ & $5.63, \mathrm{~d}(7.6)$ & $7.59, \mathrm{~s}$ \\
\hline $\begin{array}{l}2^{\prime \prime} / 2^{\prime \prime \prime} \\
3^{\prime \prime} / 3^{\prime \prime \prime}\end{array}$ & $6.46, \mathrm{~d}(2.1)$ & $6.73, \mathrm{~d}(1.8)$ & $6.43, \mathrm{~d}(1.8)$ & 6.65 , br s & $6.65, \mathrm{~d}(2.1)$ & $6.51, \mathrm{~d}(2.1)$ & $6.45, \mathrm{~d}(2.1)$ & $\begin{array}{l}7.06, \mathrm{~d}(8.6) \\
7.76, \mathrm{~d}(8.6)\end{array}$ \\
\hline $5^{\prime \prime} / 5^{\prime \prime \prime}$ & $6.67, \mathrm{~d}(8.1)$ & $6.65, \mathrm{~d}(8.0)$ & $6.65, \mathrm{~d}(6.7)$ & $6.71, \mathrm{~d}(8.2)$ & $6.75, \mathrm{~d}(8.2)$ & $6.67, \mathrm{~d}(8.2)$ & $6.67, \mathrm{~d}(8.2)$ & $7.76, \mathrm{~d}(8.6)$ \\
\hline $6^{\prime \prime} / 6^{\prime \prime \prime}$ & $6.32, \mathrm{dd}(8.1,2.1)$ & $\begin{array}{l}6.59, \mathrm{dd} \\
(8.0,1.8)\end{array}$ & $\begin{array}{l}6.29, \mathrm{dd} \\
(8.2,1.8)\end{array}$ & $\begin{array}{l}6.55, \mathrm{dd} \\
(8.2,1.8)\end{array}$ & $\begin{array}{l}6.55, \mathrm{~d} \\
(8.2,2.1)\end{array}$ & $\begin{array}{l}6.32, \mathrm{~d} \\
(8.2,2.1)\end{array}$ & $6.31, \mathrm{dd}(8.2,2.1)$ & $7.06, \mathrm{~d}(8.6)$ \\
\hline $7^{\prime \prime} / 7^{\prime \prime \prime}$ & $2.52, \mathrm{~m}$ & $2.93, \mathrm{~m}$ & $2.49, \mathrm{~m}$ & $2.88, \mathrm{~m}$ & $2.60, \mathrm{~m}$ & $2.82, \mathrm{~m}$ & $2.51, \mathrm{~m}$ & $2.94, \mathrm{~m}$ \\
\hline $8^{\prime \prime} / 8^{\prime \prime \prime}$ & $2.64, \mathrm{~m}$ & $2.93, \mathrm{~m}$ & $2.62, \mathrm{~m}$ & $2.88, \mathrm{~m}$ & $2.60, \mathrm{~m}$ & $2.82, \mathrm{~m}$ & $2.64, \mathrm{~m}$ & $2.91, \mathrm{~m}$ \\
\hline $\mathrm{OCH}_{3}$ & $3.75, \mathrm{~s}\left(4^{\prime \prime}-\mathrm{OCH}_{3}\right)$ & $\begin{array}{l}3.92, \mathrm{~s} \\
\left(6^{\prime}-\mathrm{OCH}_{3}\right) \\
3.74, \mathrm{~s} \\
\left(3^{\prime \prime \prime}-\mathrm{OCH}_{3}\right)\end{array}$ & $\begin{array}{l}3.75, \mathrm{~s} \\
\left(4^{\prime \prime}-\mathrm{OCH}_{3}\right)\end{array}$ & $\begin{array}{l}3.90, \mathrm{~s} \\
\left(6^{\prime}-\mathrm{OCH}_{3}\right) \\
3.74, \mathrm{~s} \\
\left(4^{\prime \prime \prime}-\mathrm{OCH}_{3}\right)\end{array}$ & $\begin{array}{l}3.69, \mathrm{~s} \\
\left(4^{\prime \prime}-\mathrm{OCH}_{3}\right)\end{array}$ & $\begin{array}{l}3.68, \mathrm{~s} \\
\left(4^{\prime \prime \prime}-\mathrm{OCH}_{3}\right)\end{array}$ & $3.75, \mathrm{~s}\left(4^{\prime \prime}-\mathrm{OCH}_{3}\right)$ & $\begin{array}{l}3.93, \mathrm{~s} \\
\left(6^{\prime}-\mathrm{OCH}_{3}\right) \\
3.71, \mathrm{~s} \\
\left(4^{\prime \prime \prime}-\mathrm{OCH}_{3}\right)\end{array}$ \\
\hline
\end{tabular}

${ }^{a}$ Measured in $\mathrm{CD}_{3} \mathrm{OD} .{ }^{b}$ Measured in DMSO- $d_{6}$. 
Table $2{ }^{13} \mathrm{C}$ NMR spectroscopic data for compounds $1-4(1-3$ at $125 \mathrm{MHz}, 4$ at $150 \mathrm{MHz}, \delta$ in ppm)

\begin{tabular}{|c|c|c|c|c|c|c|c|c|}
\hline \multirow[b]{2}{*}{ Position } & \multicolumn{2}{|l|}{$\mathbf{1}^{a}$} & \multicolumn{2}{|l|}{$2^{a}$} & \multicolumn{2}{|l|}{$3^{b}$} & \multicolumn{2}{|l|}{$4^{a}$} \\
\hline & Unit A & Unit B & Unit A & Unit B & Unit A & Unit B & Unit A & Unit B \\
\hline $3 / 3^{\prime}$ & 114.5, CH & $110.1, \mathrm{CH}$ & $114.5, \mathrm{CH}$ & $110.1, \mathrm{CH}$ & $113.2, \mathrm{CH}$ & 108.7, CH & $114.5, \mathrm{CH}$ & 110.1, CH \\
\hline $4 / 4^{\prime}$ & 181.4, C & $179.8, \mathrm{C}$ & 181.5, C & $179.8, \mathrm{C}$ & 178.0, C & 176.1, C & $181.5, \mathrm{C}$ & $179.8, \mathrm{C}$ \\
\hline $5 / 5^{\prime}$ & $66.3, \mathrm{CH}$ & $105.8, \mathrm{CH}$ & $66.4, \mathrm{CH}$ & $105.8, \mathrm{CH}$ & $64.4, \mathrm{CH}$ & 108.1, CH & $66.3, \mathrm{CH}$ & $105.8, \mathrm{CH}$ \\
\hline $8 / 8^{\prime}$ & $78.3, \mathrm{CH}$ & $105.2, \mathrm{CH}$ & $78.3, \mathrm{CH}$ & $105.2, \mathrm{CH}$ & $77.9, \mathrm{CH}$ & $104.2, \mathrm{CH}$ & $78.3, \mathrm{CH}$ & 105.1, CH \\
\hline $9 / 9^{\prime}$ & 162.0, C & 153.9, C & 162.0, C & $153.8, \mathrm{C}$ & 159.5, C & $150.5, \mathrm{C}$ & 162.0, C & 153.9, C \\
\hline $10 / 10^{\prime}$ & $122.9, \mathrm{C}$ & 118.6, C & $122.9, \mathrm{C}$ & 118.5, C & 121.8, C & 117.7, C & $122.9, \mathrm{C}$ & $118.5, \mathrm{C}$ \\
\hline $1^{\prime \prime} / 1^{\prime \prime \prime}$ & $133.8, \mathrm{C}$ & $132.8, \mathrm{C}$ & $133.8, \mathrm{C}$ & 134.2, C & 132.5, C & 132.7, C & $133.8, \mathrm{C}$ & 133.2, C \\
\hline $2^{\prime \prime} / 2^{\prime \prime \prime}$ & 116.2, CH & 113.1, CH & $116.2, \mathrm{CH}$ & 116.4, CH & $115.7, \mathrm{CH}$ & $115.5, \mathrm{CH}$ & $116.2, \mathrm{CH}$ & $130.4, \mathrm{CH}$ \\
\hline $3^{\prime \prime} / 3^{\prime \prime \prime}$ & 147.6, C & $149.9, \mathrm{C}$ & $147.6, \mathrm{C}$ & 147.6, C & $146.3, \mathrm{C}$ & 146.3, C & $147.6, \mathrm{C}$ & $114.9, \mathrm{CH}$ \\
\hline $8^{\prime \prime} / 8^{\prime \prime \prime}$ & $36.6, \mathrm{CH}_{2}$ & $37.3, \mathrm{CH}_{2}$ & $36.5, \mathrm{CH}_{2}$ & $37.0, \mathrm{CH}_{2}$ & $34.6, \mathrm{CH}_{2}$ & $35.2, \mathrm{CH}_{2}$ & $36.6, \mathrm{CH}_{2}$ & $37.2, \mathrm{CH}_{2}$ \\
\hline $\mathrm{OCH}_{3}$ & $56.4\left(4^{\prime \prime}-\mathrm{OCH}_{3}\right)$ & $56.7\left(6^{\prime}-\mathrm{OCH}_{3}\right)$ & $56.4\left(4^{\prime \prime}-\mathrm{OCH}_{3}\right)$ & $56.8\left(6^{\prime}-\mathrm{OCH}_{3}\right)$ & $55.6\left(4^{\prime \prime}-\mathrm{OCH}_{3}\right)$ & $55.6\left(4^{\prime \prime \prime}-\mathrm{OCH}_{3}\right)$ & $56.4\left(4^{\prime \prime}-\mathrm{OCH}_{3}\right)$ & $56.7\left(6^{\prime}-\mathrm{OCH}_{3}\right)$ \\
\hline & & $56.3\left(3^{\prime \prime \prime}-\mathrm{OCH}_{3}\right)$ & & $56.4\left(4^{\prime \prime \prime}-\mathrm{OCH}_{3}\right)$ & & & & $55.6\left(4^{\prime \prime \prime}-\mathrm{OCH}_{3}\right)$ \\
\hline
\end{tabular}

${ }^{a}$ Measured in $\mathrm{CD}_{3} \mathrm{OD} .{ }^{b}$ Measured in DMSO- $d_{6}$.

Data comparison revealed that the structure of 3 closely resembled that of 2 , except for the $6^{\prime}-\mathrm{OH}$ rather than $6^{\prime}-\mathrm{OCH}_{3}$ in 2 , which was confirmed by the 14 amu difference between their molecular weights. The two methoxyl groups in the structure were located at $\mathrm{C}-4^{\prime \prime}$ and $\mathrm{C}-4^{\prime \prime \prime}$ according to the ROESY correlations of $4^{\prime \prime}-\mathrm{OCH}_{3}\left(\delta_{\mathrm{H}} 3.69\right) / \mathrm{H}-5^{\prime \prime}\left(\delta_{\mathrm{H}} 6.75\right)$ and $4^{\prime \prime \prime}-\mathrm{OCH}_{3}\left(\delta_{\mathrm{H}} 3.68\right) /$ $\mathrm{H}-5^{\prime \prime \prime}\left(\delta_{\mathrm{H}} 6.67\right)$, respectively. The downfield chemical shift of C- $6^{\prime}$ $\left(\delta_{\mathrm{C}} 146.3\right)$ revealed oxygenation at $\mathrm{C}-6^{\prime}$, and the molecular formula indicated that a hydroxyl group was located at C- 6 ' . The relative configuration of 3 was deduced to be the same as that of 1 due to their similar ${ }^{3} J_{\mathrm{H}-\mathrm{H}}$ coupling constants for $\mathrm{H}-5 / \mathrm{H}-6 / \mathrm{H}-7 /$ $\mathrm{H}-8$. The absorption in the ECD curve of $\mathbf{3}$ was close to zero, which indicated the existence of a racemate. Thus, compound 3 was identified as aquilasinenone $\mathrm{C}$.

Aquilasinenone D (4) was obtained as a colorless oil, and its molecular formula was established as $\mathrm{C}_{37} \mathrm{H}_{36} \mathrm{O}_{12}$ based on the

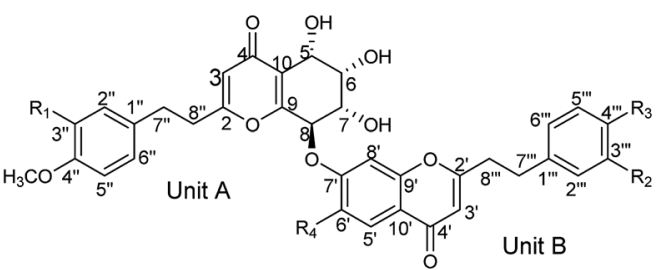

$1 \mathrm{R}_{1}=\mathrm{OH} \mathrm{R} \mathrm{R}_{2}=\mathrm{OCH}_{3} \quad \mathrm{R}_{3}=\mathrm{OH} \mathrm{R} \mathrm{R}_{4}=\mathrm{OCH}_{3}$

$2 \mathrm{R}_{1}=\mathrm{OH} \mathrm{R} \mathrm{R}_{2}=\mathrm{OH} \mathrm{R} \mathrm{R}_{3}=\mathrm{OCH}_{3} \mathrm{R}_{4}=\mathrm{OCH}_{3}$

$3 \mathrm{R}_{1}=\mathrm{OH} \quad \mathrm{R}_{2}=\mathrm{OH} \quad \mathrm{R}_{3}=\mathrm{OCH}_{3} \quad \mathrm{R}_{4}=\mathrm{OH}$

$4 \mathrm{R}_{1}=\mathrm{OH} \mathrm{R} \quad=\mathrm{H}_{3}=\mathrm{OCH}_{3} \quad \mathrm{R}_{4}=\mathrm{OCH}_{3}$

$5 \quad \mathrm{R}_{1}=\mathrm{H} \mathrm{R}_{2}=\mathrm{OCH}_{3} \quad \mathrm{R}_{3}=\mathrm{OH} \quad \mathrm{R}_{4}=\mathrm{OCH}_{3}$<smiles>COc1ccc(CCc2cc(=O)c3cc(O[C@@H]4c5oc(CCc6ccccc6)cc(=O)c5[C@@H](O)[C@H](O)[C@H]4O)ccc3o2)cc1O</smiles>

10

Fig. 1 Structures of compounds 1-11.<smiles>[R]c1ccc(CCc2cc(=O)c3c(o2)[C@H](Oc2cc4oc(CCc5ccc([R4])c([R])c5)cc(=O)c4cc2OC)[C@H](O)[C@@H](O)[C@H]3O)cc1[R]</smiles>

$6 \quad \mathrm{R}_{1}=\mathrm{OH} \quad \mathrm{R}_{2}=\mathrm{OCH}_{3} \quad \mathrm{R}_{3}=\mathrm{OCH}_{3} \quad \mathrm{R}_{4}=\mathrm{OH}$

$7 \quad \mathrm{R}_{1}=\mathrm{OH} \mathrm{R} \mathrm{R}_{2}=\mathrm{OCH}_{3} \quad \mathrm{R}_{3}=\mathrm{OH} \quad \mathrm{R}_{4}=\mathrm{OCH}_{3}$

$8 \quad \mathrm{R}_{1}=\mathrm{OCH}_{3} \quad \mathrm{R}_{2}=\mathrm{OH} \quad \mathrm{R}_{3}=\mathrm{OCH}_{3} \quad \mathrm{R}_{4}=\mathrm{OH}$

$9 \quad \mathrm{R}_{1}=\mathrm{H} \mathrm{R}_{2}=\mathrm{OCH}_{3} \quad \mathrm{R}_{3}=\mathrm{OH} \mathrm{R} \mathrm{R}_{4}=\mathrm{OCH}_{3}$<smiles>COc1ccc(CCc2cc(=O)c3c(o2)C(O)[C@H](O)[C@H](O)[C@H]3Oc2cc3oc(CCc4ccc(O)c(OC)c4)cc(=O)c3cc2OC)cc1O</smiles>

11 

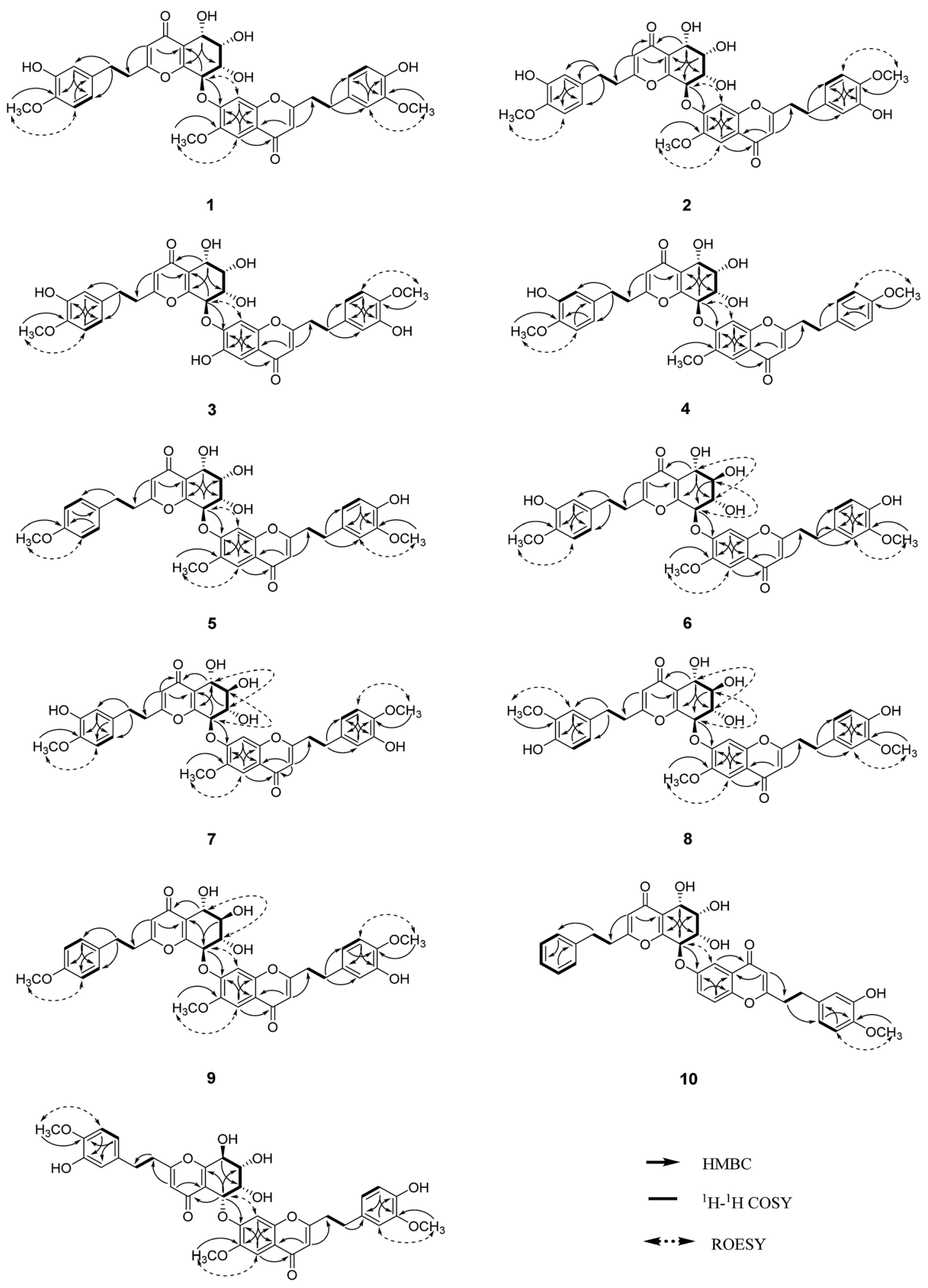

10

11

Fig. 2 Key 2D NMR correlations of compounds 1-11.

HRESIMS pseudomolecular ion peak at $m / z$ 695.2095 $[\mathrm{M}+\mathrm{Na}]^{+}$ (calcd for $\mathrm{C}_{37} \mathrm{H}_{36} \mathrm{NaO}_{12}$, 695.2099). The comparison of corresponding NMR data revealed that compound 4 was similar to that of 2, except for the substitutions on the phenylethyl part of the aromatic system in unit $\mathrm{B}$. A typical $\mathrm{AA}^{\prime} \mathrm{BB}^{\prime}$ aromatic system in contrast to the ABX coupling system in 2 was deduced from the NMR data (Table 1), and the 4-methoxyl group was confirmed by the HMBC correlation from $4^{\prime \prime \prime}-\mathrm{OCH}_{3}\left(\delta_{\mathrm{H}} 3.71\right)$ to 
Table $3{ }^{1} \mathrm{H}$ NMR spectroscopic data for compounds 5-8 (5-7 at $500 \mathrm{MHz}, 8$ at $600 \mathrm{MHz}, \delta$ in ppm, $\mathrm{J}$ in $\mathrm{Hz}$, measured in $\mathrm{CD}{ }_{3} \mathrm{OD}$ )

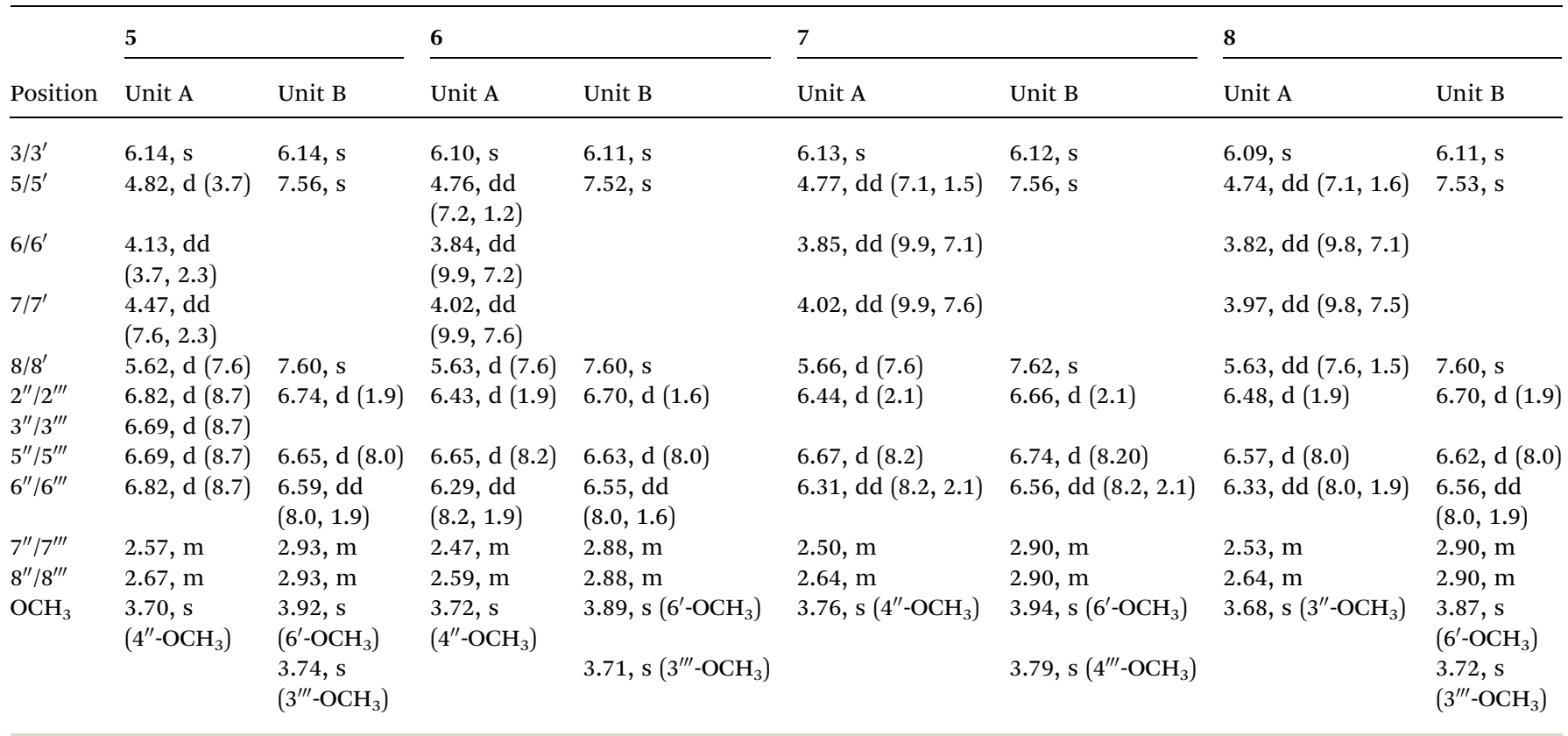

$\mathrm{C}-4^{\prime \prime \prime}\left(\delta_{\mathrm{C}} 159.7\right)$, as well as the ROESY correlation of $4^{\prime \prime \prime}-\mathrm{OCH}_{3}\left(\delta_{\mathrm{H}}\right.$ $3.71) / \mathrm{H}-3^{\prime \prime \prime}\left(\delta_{\mathrm{H}} 7.76\right)$. The presence of $\mathrm{C} 8-\mathrm{O}-\mathrm{C} 7^{\prime}$ linkage connecting units $\mathrm{A}$ and $\mathrm{B}$ was deduced according to the $\mathrm{HMBC}$ correlation from $\mathrm{H}-8\left(\delta_{\mathrm{H}} 5.63\right)$ to the phenyl carbon $\mathrm{C}-7^{\prime}\left(\delta_{\mathrm{C}}\right.$ 156.2 ), as well as the ROESY correlation of $\mathrm{H}-8 / \mathrm{H}-\mathrm{8}^{\prime}$. The relative configuration of $\mathbf{4}$ was deduced to be the same as that of $\mathbf{1}$ due to their similar ${ }^{3} \mathrm{~J}_{\mathrm{H}-\mathrm{H}}$ coupling constants for $\mathrm{H}-5 / \mathrm{H}-6 / \mathrm{H}-7 / \mathrm{H}-8$. The absolute configuration of $(5 S, 6 S, 7 S, 8 R)$ was determined by analyzing its ECD data, which were the same as those of $\mathbf{1}$. Therefore, compound $\mathbf{4}$ was identified as aquilasinenone D.
Aquilasinenone E (5) was obtained as a colorless oil, and its molecular formula was established as $\mathrm{C}_{37} \mathrm{H}_{36} \mathrm{O}_{12}$ based on the HRESIMS pseudomolecular ion peak at $m / z 695.2108[\mathrm{M}+\mathrm{Na}]^{+}$ (calcd for $\mathrm{C}_{37} \mathrm{H}_{36} \mathrm{NaO}_{12}, 695.2099$ ). Analysis of the ${ }^{1} \mathrm{H}$ and ${ }^{13} \mathrm{C}$ NMR spectroscopic data (Tables 3 and 4) of 5 showed a close structural resemblance to that of $\mathbf{1}$. The major difference was the presence of one para-disubstituted methoxyl benzene moiety in unit $\mathrm{A}$. These assignments were corroborated by the typical $\mathrm{AA}^{\prime} \mathrm{BB}^{\prime}$ aromatic system $\left[132.7\left(\mathrm{C}-1^{\prime \prime}\right), 6.82(2 \mathrm{H}, \mathrm{d}, J=\right.$ $\left.8.7 \mathrm{~Hz}, \mathrm{H}-2^{\prime \prime}, 6^{\prime \prime}\right) / 130.2\left(\mathrm{C}-2^{\prime \prime}, 6^{\prime \prime}\right), 6.69\left(2 \mathrm{H}, \mathrm{d}, J=8.7 \mathrm{~Hz}, \mathrm{H}-3^{\prime \prime}\right.$,

Table $4{ }^{13} \mathrm{C}$ NMR spectroscopic data for compounds 5-8 (5-7 at $125 \mathrm{MHz}, 8$ at $150 \mathrm{MHz}, \delta$ in ppm, measured in CD ${ }_{3} \mathrm{OD}$ )

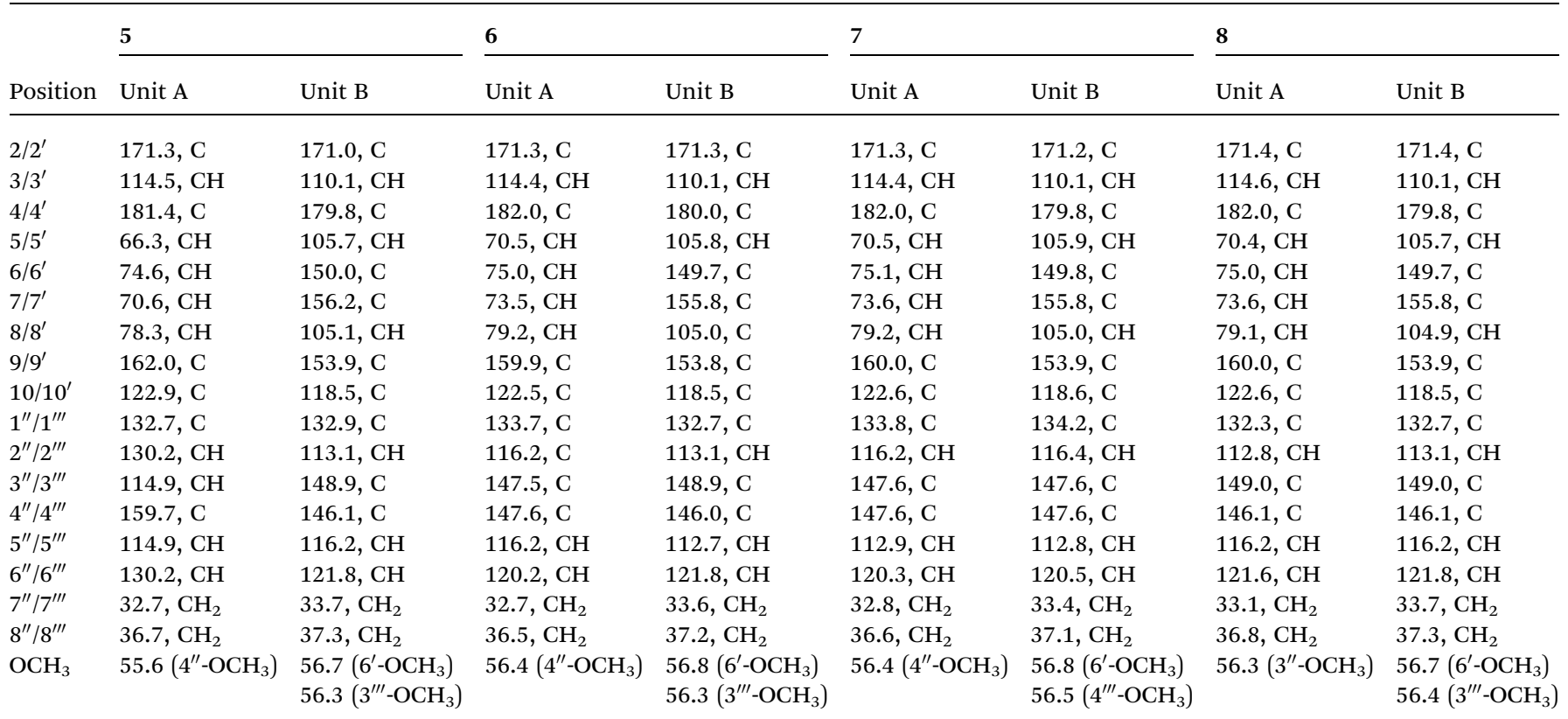




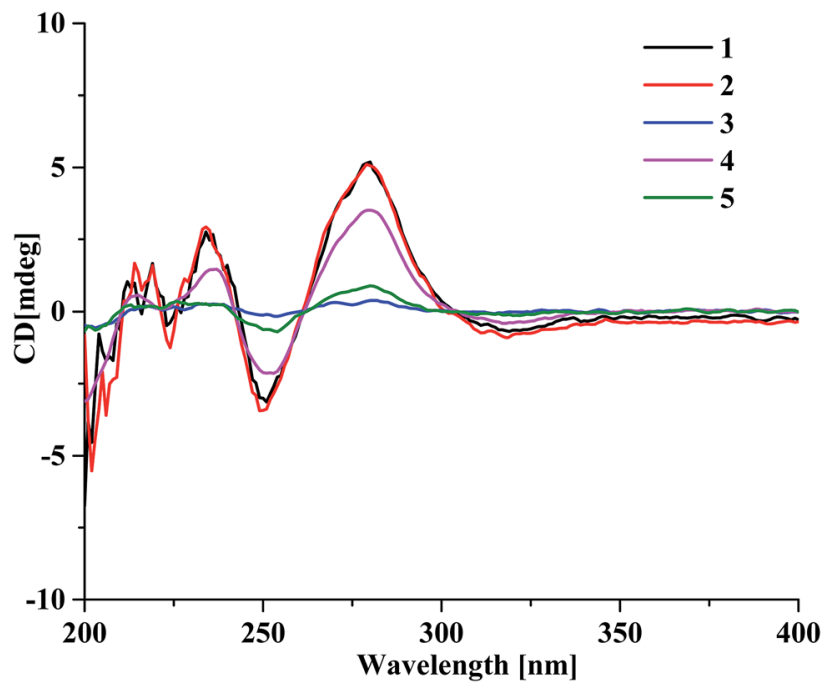

Fig. 3 The ECD spectra of compounds $1-5$.

$\left.\left.5^{\prime \prime}\right) / 114.9\left(\mathrm{C}-3^{\prime \prime}, 5^{\prime \prime}\right), 159.7\left(\mathrm{C}-4^{\prime \prime}\right)\right]$, as well as their HMBC correlation of $4^{\prime \prime}-\mathrm{OCH}_{3}\left(\delta_{\mathrm{H}} 3.70\right) / \mathrm{C}-4^{\prime \prime}$ and ROESY correlation of $4^{\prime \prime}$ $\mathrm{OCH}_{3} / \mathrm{H}-3^{\prime \prime}$. The presence of $\mathrm{C} 8-\mathrm{O}-\mathrm{C}^{\prime}$ linkage connecting units $\mathrm{A}$ and $\mathrm{B}$ was deduced according to the HMBC correlation from the proton at $\delta_{\mathrm{H}} 5.62(\mathrm{H}-8)$ to the phenyl carbon at $\delta_{\mathrm{C}} 156.2(\mathrm{C}-$ $7^{\prime}$ ), and the ROESY correlation of $\mathrm{H}-8 / \mathrm{H}-8^{\prime}$. The relative configurations of $\mathbf{5}$ were the same as those assigned for $\mathbf{1}$ on the basis of their ${ }^{3} J_{\mathrm{H}-\mathrm{H}}$ coupling constants. A racemate existed with the $(5 S, 6 S, 7 S, 8 R)$-configuration in excess, according to the slight positive Cotton effect around $\lambda_{\max } 280 \mathrm{~nm}$ and the negative Cotton effect around $\lambda_{\max } 250 \mathrm{~nm}$ in the ECD spectrum, which was similar to that of $\mathbf{1}$. Therefore, the structure was named as aquilasinenone $\mathrm{E}$.

Aquilasinenone F (6) was obtained as a yellow oil, and its molecular formula was established as $\mathrm{C}_{37} \mathrm{H}_{36} \mathrm{O}_{13}$ based on the HRESIMS pseudomolecular ion peak at $m / z$ 711.2062 [M+Na $]^{+}$ (calcd for $\mathrm{C}_{37} \mathrm{H}_{36} \mathrm{NaO}_{13}, 711.2048$ ). Upon a detailed comparison of the ${ }^{1} \mathrm{H}$ and ${ }^{13} \mathrm{C}$ NMR data of 6 with those of 1 , it was found that they shared the same planar structures. The relative configurations of the four chiral centers in unit A were deduced by the analysis of the ${ }^{3} J_{\mathrm{H}-\mathrm{H}}$ coupling constants and ROESY spectrum. The large $J$ values of $\mathrm{H}-5 / \mathrm{H}-6$ (7.2 Hz), H-6/H-7 (9.9 $\mathrm{Hz})$ and $\mathrm{H}-7 / \mathrm{H}-8(7.6 \mathrm{~Hz})$ indicated the axial orientation of these protons, which was further supported by the ROESY correlations of $\mathrm{H}-5 / \mathrm{H}-7$ and $\mathrm{H}-6 / \mathrm{H}-8$. The positive long-wave Cotton effect around $\lambda_{\max } 280 \mathrm{~nm}$ and the negative short-wave Cotton effect around $\lambda_{\max } 250 \mathrm{~nm}$ (Fig. 4) in its ECD curve were the same as those reported for $(5 S, 6 R, 7 S, 8 R)-2-[2-(4-m e t h o x y p h e n y)$ ethyl]-5,6,7-trihydroxy-5,6,7,8-tetrahydro-8-\{6-methoxy-2-[2-(3methoxy-4-hydroxyphenyl)ethyl]chromonyl-7-oxy\}chromone, ${ }^{13}$ which suggested a $(5 S, 6 R, 7 S, 8 R)$-configuration for 6 . It was named aquilasinenone $\mathrm{F}$.

Aquilasinenone G (7) was obtained as a colorless oil, and its molecular formula was established as $\mathrm{C}_{37} \mathrm{H}_{36} \mathrm{O}_{13}$ based on the HRESIMS pseudomolecular ion peak at $m / z 711.2121[\mathrm{M}+\mathrm{Na}]^{+}$ (calcd for $\mathrm{C}_{37} \mathrm{H}_{36} \mathrm{NaO}_{13}, 711.2048$ ). On comparing the ${ }^{1} \mathrm{H}$ and

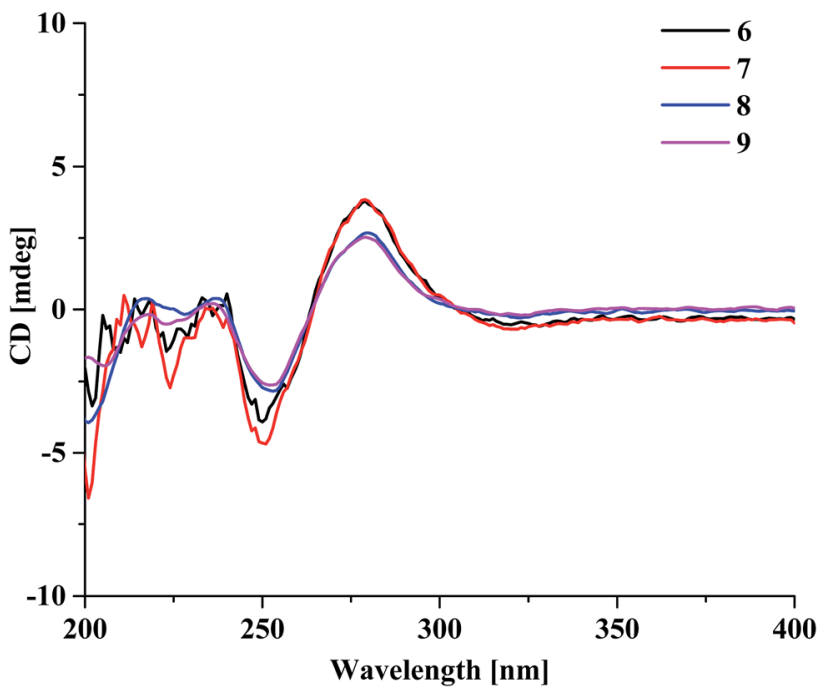

Fig. 4 The ECD spectra of compounds 6-9.

${ }^{13} \mathrm{C}$ NMR data of 7 with those of 2 , it was found that they shared the same planar structures. However, the relative configuration of 7 was deduced to be the same as that of 6 due to their similar ROESY and ${ }^{3} J_{\mathrm{H}-\mathrm{H}}$ coupling constant data for $\mathrm{H}-5 / \mathrm{H}-6 / \mathrm{H}-7 / \mathrm{H}-8$. The ECD curve (Fig. 4) of 7 showed a similar Cotton effect as that of 6 , indicating the same $(5 S, 6 R, 7 S, 8 R)$-configuration. Thus, the structure of aquilasinenone $\mathrm{G}$ was established.

Aquilasinenone $\mathrm{H}(\mathbf{8})$ was obtained as a colorless oil, and its molecular formula was established as $\mathrm{C}_{37} \mathrm{H}_{36} \mathrm{O}_{13}$ based on the HRESIMS pseudomolecular ion peak at $m / z 711.2046[\mathrm{M}+\mathrm{Na}]^{+}$ (calcd for $\mathrm{C}_{37} \mathrm{H}_{36} \mathrm{NaO}_{13}, 711.2048$ ). Comparison of the $1 \mathrm{D}$ and 2D NMR spectroscopic data (Tables 3 and 4) of 8 showed a close structural resemblance to that of $\mathbf{6}$, and both shared the same relative configuration on the $4 H$-chromone part. The main differences were the substitutions for $4^{\prime \prime}-\mathrm{OH}$ and $3^{\prime \prime}-\mathrm{OCH}_{3}$ on the benzene moiety in unit $\mathrm{A}$. These assignments were verified by the HMBC correlations of $\mathrm{H}-2^{\prime \prime}\left(\delta_{\mathrm{H}} 6.48\right) / \mathrm{C}-4^{\prime \prime}\left(\delta_{\mathrm{C}} 146.1\right)$ and $\mathrm{H}-5^{\prime \prime}\left(\delta_{\mathrm{H}} 6.57\right) / \mathrm{C}-1^{\prime \prime}\left(\delta_{\mathrm{C}} 132.3\right)$, and the ROESY correlation of $3^{\prime \prime}-$ $\mathrm{OCH}_{3}\left(\delta_{\mathrm{H}} 3.68\right) / \mathrm{H}-2^{\prime \prime}$. The absolute configuration of $\mathrm{C}-8$ was deduced to be the same as that of 6 based on their similar ECD spectra. Thus, the structure of aquilasinenone $\mathrm{H}$ was established.

Aquilasinenone I (9) was obtained as a yellow oil, and its molecular formula was established as $\mathrm{C}_{37} \mathrm{H}_{36} \mathrm{O}_{12}$ based on the HRESIMS pseudomolecular ion peak at $m / z 671.2145[\mathrm{M}-\mathrm{H}]^{-}$ (calcd for $\mathrm{C}_{37} \mathrm{H}_{35} \mathrm{O}_{12}, 671.2134$ ). A comparison of its $1 \mathrm{D}$ and $2 \mathrm{D}$ NMR spectroscopic data (Tables 5 and 6) with those of 7 revealed that they shared similar structures, with the main difference being the para-disubstituted methoxyl benzene moiety in unit A of 9. These assignments were verified by the HMBC correlation of $4^{\prime \prime}-\mathrm{OCH}_{3}\left(\delta_{\mathrm{H}} 3.70\right) / \mathrm{C}-4^{\prime \prime}\left(\delta_{\mathrm{C}} 159.7\right)$, the ROESY correlation from $4^{\prime \prime}-\mathrm{OCH}_{3}$ to $\mathrm{H}-3^{\prime \prime} / 5^{\prime \prime}\left(\delta_{\mathrm{H}} 6.69\right)$, as well as the typical $\mathrm{AA}^{\prime} \mathrm{BB}^{\prime}$ aromatic coupling system $\left[\delta_{\mathrm{C}} 132.8\left(\mathrm{C}-1^{\prime \prime}\right), \delta_{\mathrm{C}}\right.$ $130.1 / \delta_{\mathrm{H}} 6.80\left(2 \mathrm{H}, \mathrm{d}, J=8.6 \mathrm{~Hz}, \mathrm{H}-2^{\prime \prime}, 6^{\prime \prime}\right), \delta_{\mathrm{C}} 114.9 / \delta_{\mathrm{H}} 6.69(2 \mathrm{H}$, $\left.\left.\mathrm{d}, J=8.6 \mathrm{~Hz}, \mathrm{H}-3^{\prime \prime}, 5^{\prime \prime}\right), \delta_{\mathrm{C}} 159.7\left(\mathrm{C}-4^{\prime \prime}\right)\right]$. The relative configuration of 9 was deduced to be the same as that of 6 , and the 
Table $5{ }^{1} \mathrm{H}$ NMR spectroscopic data for compounds 9-11 (500 MHz, $\delta$ in ppm, $\mathrm{J}$ in $\mathrm{Hz}$, measured in $\mathrm{CD}_{3} \mathrm{OD}$ )

\begin{tabular}{|c|c|c|c|c|c|c|}
\hline \multirow[b]{2}{*}{ Position } & \multicolumn{2}{|l|}{9} & \multicolumn{2}{|l|}{10} & \multicolumn{2}{|l|}{11} \\
\hline & Unit A & Unit B & Unit A & Unit B & Unit A & Unit B \\
\hline $3 / 3^{\prime}$ & $6.13, \mathrm{~s}$ & $6.13, \mathrm{~s}$ & $6.15, \mathrm{~s}$ & $6.15, \mathrm{~s}$ & $6.15, \mathrm{~s}$ & $6.11, \mathrm{~s}$ \\
\hline $5 / 5^{\prime}$ & $4.77, \mathrm{~d}(7.2)$ & $7.55, \mathrm{~s}$ & $4.80, \mathrm{~d}(3.8)$ & $7.90, \mathrm{dd}(4.0,2.2)$ & $5.50, \mathrm{~d}(3.2)$ & $7.47, \mathrm{~s}$ \\
\hline $6 / 6^{\prime}$ & 3.84, dd $(9.9,7.2)$ & & 4.10, dd $(3.8,2.3)$ & & $4.23, \mathrm{~m}$ & \\
\hline $7 / 7^{\prime}$ & 4.01, dd (9.9) & & 4.38, dd $(7.7,2.3)$ & $7.62, \mathrm{~d}(1.7)$ & 4.14, dd $(8.2,2.3)$ & \\
\hline $8 / 8^{\prime}$ & $5.68, \mathrm{~m}$ & $7.64, \mathrm{~s}$ & $5.46, \mathrm{~d}(7.7)$ & $7.62, \mathrm{~d}(1.7)$ & $4.67, \mathrm{~d}(8.2)$ & $7.54, \mathrm{~s}$ \\
\hline $2^{\prime \prime} / 2^{\prime \prime \prime}$ & $6.80, \mathrm{~d}(8.6)$ & $6.65, \mathrm{~d}(2.0)$ & $6.93, \mathrm{~d}(6.7)$ & $6.70, \mathrm{~d}(2.1)$ & $6.72, \mathrm{~d}(2.0)$ & $6.76, \mathrm{~d}(1.8)$ \\
\hline $3^{\prime \prime} / 3^{\prime \prime \prime}$ & $6.69, \mathrm{~d}(8.6)$ & & $7.13, \mathrm{t}(7.4)$ & & & \\
\hline $4^{\prime \prime} / 4^{\prime \prime \prime}$ & & & $7.10, \mathrm{t}(7.4)$ & & & \\
\hline $5^{\prime \prime} / 5^{\prime \prime \prime}$ & $6.69, \mathrm{~d}(8.6)$ & $6.72, \mathrm{~d}(8.2)$ & $7.13, \mathrm{t}(7.4)$ & $6.76, \mathrm{~d}(8.2)$ & $6.83, \mathrm{~d}(8.2)$ & $6.69, \mathrm{~d}(1.8)$ \\
\hline $6^{\prime \prime} / 6^{\prime \prime \prime}$ & $6.80, \mathrm{~d}(8.6)$ & $6.55, \mathrm{dd}(8.2,2.0)$ & $6.93, \mathrm{~d}(6.7)$ & 6.62, dd $(8.2,2.1)$ & 6.67, dd $(8.2,2.0)$ & 6.65, dd $(8.0,1.8)$ \\
\hline $7^{\prime \prime} / 7^{\prime \prime \prime}$ & $2.56, \mathrm{~m}$ & $2.90, \mathrm{~m}$ & $2.61, \mathrm{~m}$ & $2.97, \mathrm{~m}$ & $2.93, \mathrm{~m}$ & $2.97, \mathrm{~m}$ \\
\hline $8^{\prime \prime} / 8^{\prime \prime \prime}$ & $2.56, \mathrm{~m}$ & $2.90, \mathrm{~m}$ & $2.71, \mathrm{~m}$ & $2.97, \mathrm{~m}$ & $2.94, \mathrm{~m}$ & $3.01, \mathrm{~m}$ \\
\hline $\mathrm{OCH}_{3}$ & $3.70, \mathrm{~s}\left(4^{\prime \prime}-\mathrm{OCH}_{3}\right)$ & $3.76, \mathrm{~s}\left(4^{\prime \prime \prime}-\mathrm{OCH}_{3}\right)$ & & $3.77, \mathrm{~s}\left(4^{\prime \prime \prime}-\mathrm{OCH}_{3}\right)$ & $3.75, \mathrm{~s}\left(4^{\prime \prime}-\mathrm{OCH}_{3}\right)$ & $\begin{array}{l}3.86, \mathrm{~s}\left(6^{\prime}-\mathrm{OCH}_{3}\right) \\
3.74, \mathrm{~s}\left(3^{\prime \prime \prime}-\mathrm{OCH}_{3}\right)\end{array}$ \\
\hline
\end{tabular}

absolute configuration of C-8 was determined to be $R$ via the analysis of its ECD data, indicating the same $(5 S, 6 R, 7 S, 8 R)$ configuration. Therefore, compound $\mathbf{9}$ was identified as aquilasinenone I.

Aquilasinenone $\mathrm{J}$ (10) was obtained as a yellow oil, and its molecular formula was established as $\mathrm{C}_{35} \mathrm{H}_{32} \mathrm{O}_{10}$ based on the HRESIMS pseudomolecular ion peak at $m / z$ 635.1909 $[\mathrm{M}+\mathrm{Na}]^{+}$ (calcd for $\mathrm{C}_{35} \mathrm{H}_{32} \mathrm{NaO}_{10}, 635.1888$ ). The comparison of the ${ }^{1} \mathrm{H}$ and ${ }^{13} \mathrm{C}$ NMR spectroscopic data of $\mathbf{1 0}$ and those of $(5 S, 6 R, 7 S, 8 R)$-2-(2-phenylethyl)-5,6,7-trihydroxy-5,6,7,8-tetrahydro-8-[2-(2-phenylethyl)chromonyl-6-oxy] chromone $^{16}$ indicated that they shared the same structure for unit A, and the difference being the replacement of the mono-substituted aromatic ring by a 1,3,4-trisubstituted aromatic ring in unit B in 10. These assignments were verified by the presence of an $\mathrm{ABX}$ aromatic coupling system $\left[\delta_{\mathrm{C}} 134.1\left(\mathrm{C}-1^{\prime \prime \prime}\right), \delta_{\mathrm{C}} 116.4 / \delta_{\mathrm{H}} 6.70(1 \mathrm{H}, \mathrm{d}, J=\right.$ $\left.2.1 \mathrm{~Hz}, \mathrm{H}-2^{\prime \prime \prime}\right), \delta_{\mathrm{C}} 147.6\left(\mathrm{C}-3^{\prime \prime \prime}, 4^{\prime \prime \prime}\right), \delta_{\mathrm{C}} 112.8 / \delta_{\mathrm{H}} 6.76(1 \mathrm{H}, \mathrm{d}, J=$ $\left.\left.8.2 \mathrm{~Hz}, \mathrm{H}-5^{\prime \prime \prime}\right), \delta_{\mathrm{C}} 120.5 / \delta_{\mathrm{H}} 6.62\left(1 \mathrm{H}, \mathrm{dd}, J=8.2,2.1 \mathrm{~Hz}, \mathrm{H}-6^{\prime \prime \prime}\right)\right]$ together with the HMBC correlations of $\mathrm{H}-6^{\prime \prime \prime} / \mathrm{C}-4^{\prime \prime \prime}$ and $\mathrm{H}-5^{\prime \prime \prime} / \mathrm{C}-$ $3^{\prime \prime \prime}$, and the ROESY correlation of $4^{\prime \prime \prime}-\mathrm{OCH}_{3}\left(\delta_{\mathrm{H}} 3.77\right) / \mathrm{H}-5^{\prime \prime \prime}$, which inferred the substitutions of $3^{\prime \prime \prime}-\mathrm{OH}$ and $4^{\prime \prime \prime}-\mathrm{OCH}_{3}$. The presence of $\mathrm{C} 8-\mathrm{O}-\mathrm{C6}^{\prime}$ linkage connecting units A and B was deduced according to the HMBC correlation from the proton $\mathrm{H}$ $8\left(\delta_{\mathrm{H}} 5.46\right)$ to the phenyl carbon C- $6^{\prime}\left(\delta_{\mathrm{C}} 158.6\right)$ and the ROESY correlation of $\mathrm{H}-8 / \mathrm{H}-5^{\prime}$. The relative configuration of 10 was deduced to be the same as that of 1 due to their similar ${ }^{3} \mathrm{~J}_{\mathrm{H}-\mathrm{H}}$ coupling constants for $\mathrm{H}-5 / \mathrm{H}-6 / \mathrm{H}-7 / \mathrm{H}-8$. Thus, the structure of aquilasinenone $\mathrm{J}$ was established.

Aquilasinenone K (11) was obtained as a yellow oil, and its molecular formula was established as $\mathrm{C}_{37} \mathrm{H}_{36} \mathrm{O}_{13}$ based on the

Table $6{ }^{13} \mathrm{C}$ NMR spectroscopic data for compounds 9-11 (125 MHz, $\delta$ in ppm, measured in $\left.\mathrm{CD}_{3} \mathrm{OD}\right)$

\begin{tabular}{|c|c|c|c|c|c|c|}
\hline Position & \multicolumn{2}{|l|}{9} & \multicolumn{2}{|l|}{10} & \multicolumn{2}{|l|}{11} \\
\hline $3 / 3^{\prime}$ & 114.1, CH & 110.1, CH & 114.5, CH & $110.1, \mathrm{CH}$ & $114.2, \mathrm{CH}$ & $110.2, \mathrm{CH}$ \\
\hline $4 / 4^{\prime}$ & $182.0, \mathrm{C}$ & $179.8, \mathrm{C}$ & 181.5, C & 180.2, C & 181.6, C & 179.9, C \\
\hline $5 / 5^{\prime}$ & $70.5, \mathrm{CH}$ & $105.7, \mathrm{CH}$ & $66.3, \mathrm{CH}$ & $110.4, \mathrm{CH}$ & $74.4, \mathrm{CH}$ & $105.6, \mathrm{CH}$ \\
\hline $8 / 8^{\prime}$ & $78.7, \mathrm{CH}$ & $104.9, \mathrm{CH}$ & $78.2, \mathrm{CH}$ & $120.9, \mathrm{CH}$ & 69.7, $\mathrm{CH}$ & 104.7, $\mathrm{CH}$ \\
\hline $9 / 9^{\prime}$ & $160.0, \mathrm{C}$ & $153.9, \mathrm{C}$ & $162.8, \mathrm{C}$ & $153.4, \mathrm{C}$ & 167.2, C & 154.1, C \\
\hline $10 / 10^{\prime}$ & 122.6, C & $118.5, \mathrm{C}$ & $122.7, \mathrm{C}$ & $125.0, \mathrm{C}$ & 118.7, C & $118.4, \mathrm{C}$ \\
\hline $1^{\prime \prime} / 1^{\prime \prime \prime}$ & $132.8, \mathrm{C}$ & 134.1, C & $140.9, \mathrm{C}$ & 134.1, C & 134.1, C & $132.8, \mathrm{C}$ \\
\hline $2^{\prime \prime} / 2^{\prime \prime \prime}$ & $130.1, \mathrm{CH}$ & $116.4, \mathrm{CH}$ & $129.2, \mathrm{CH}$ & 116.4, CH & $116.4, \mathrm{CH}$ & 113.1, CH \\
\hline $3^{\prime \prime} / 3^{\prime \prime \prime}$ & $114.9, \mathrm{CH}$ & $147.6, \mathrm{C}$ & $129.5, \mathrm{CH}$ & $147.6, \mathrm{C}$ & $147.6, \mathrm{C}$ & $148.9, \mathrm{C}$ \\
\hline $8^{\prime \prime} / 8^{\prime \prime \prime}$ & $36.8, \mathrm{CH}_{2}$ & $37.1, \mathrm{CH}_{2}$ & $36.2, \mathrm{CH}_{2}$ & $37.2, \mathrm{CH}_{2}$ & $36.5, \mathrm{CH}_{2}$ & $37.4, \mathrm{CH}_{2}$ \\
\hline $\mathrm{OCH}_{3}$ & $55.6\left(4^{\prime \prime}-\mathrm{OCH}_{3}\right)$ & $56.4\left(4^{\prime \prime \prime}-\mathrm{OCH}_{3}\right)$ & & $56.4\left(4^{\prime \prime \prime}-\mathrm{OCH}_{3}\right)$ & $56.5\left(4^{\prime \prime}-\mathrm{OCH}_{3}\right)$ & $56.7\left(6^{\prime}-\mathrm{OCH}_{3}\right)$ \\
\hline
\end{tabular}


Table 7 AChE inhibitory activity of compounds 9-11 at $50 \mu \mathrm{g} \mathrm{mL}^{-1}$

\begin{tabular}{lll}
\hline Compound & $\begin{array}{l}\text { Concentration } \\
(\mu \mathrm{M})\end{array}$ & $\begin{array}{l}\text { Inhibitory } \\
\text { ratio }(\%)\end{array}$ \\
\hline $\mathbf{9}$ & 1.49 & 15.66 \\
$\mathbf{1 0}$ & 1.63 & 16.80 \\
$\mathbf{1 1}$ & 1.89 & 16.82 \\
Tacrine $^{a}$ & 0.33 & 65.76 \\
${ }^{a}$ Tacrine is $^{2}$ &
\end{tabular}

HRESIMS pseudomolecular ion peak at $m / z 711.2106[\mathrm{M}+\mathrm{Na}]^{+}$ (calcd for $\mathrm{C}_{37} \mathrm{H}_{36} \mathrm{NaO}_{13}, 711.2048$ ). A comparison of the $1 \mathrm{D}$ and 2D NMR spectroscopic data (Tables 5 and 6) of 11 showed that units A and B were the same as those in 1, respectively. Detailed analysis revealed that the major difference was the linkage between units A and B via $\mathrm{C}^{-}-\mathrm{O}-\mathrm{C}^{\prime}$ in 11. This assignment was verified by the HMBC correlations from $\mathrm{H}-5\left(\delta_{\mathrm{H}} 5.50\right)$ to $\mathrm{C}-7^{\prime}\left(\delta_{\mathrm{C}}\right.$ 155.0), as well as with the ROESY correlation of $\mathrm{H}-5 / \mathrm{H}-8^{\prime}\left(\delta_{\mathrm{H}}\right.$ 7.54). Thus, the structure for aquilasinenone $\mathrm{K}$ was established as shown in Fig. 1.

For compounds $\mathbf{3}$ and $\mathbf{5}$, we tried to separate them with the available chiral column, but failed. Therefore, we have reported them as racemates. The ECD spectra of $\mathbf{1 0}$ and $\mathbf{1 1}$ were measured, but the curves could not be clearly presented; therefore, we reported their structures using relative configurations. All compounds were tested for AChE inhibitory activity; however, only compounds 9, 10 and 11 exhibited weak AChE inhibitory activity (Table 7).

\section{Conclusion}

In conclusion, eleven novel uncommon single ether linkage dimeric compounds (1-11) were isolated from the artificial hole-induced agarwood originating from Aquilaria sinensis. Herein, we reported the NMR and MS data of these compounds, as well as the absolute configurations of 1-9 using ECD spectra. Among them, compounds 9, 10 and 11 exhibited weak acetylcholinesterase (AChE) inhibitory activity.

\section{Experimental section}

\subsection{General}

${ }^{1} \mathrm{H},{ }^{13} \mathrm{C}$ and 2D NMR spectra were recorded on a Bruker AV-500 and Bruker AVIII-600 spectrometer (Bruker), and the chemical shifts were referenced to the solvent residual peaks. HRESIMS spectra were measured with an API QSTAR Pulsar mass spectrometer (Bruker). UV spectra were obtained on a Shimadzu UV2550 spectrometer (Beckman, America). IR absorptions were obtained on a Nicolet 380 FT-IR instrument (Thermo) using $\mathrm{KBr}$ pellets. Optical rotation was measured on a Rudolph Autopol III polarimeter. HPLC analysis was performed with an Agilent Technologies 1260 Infinity equipped with an Agilent DAD G1315D detector, and the separation columns were YMC-pack $\mathrm{C}_{18}$ columns $(5 \mathrm{~mm}, 250 \mathrm{~mm} \times 4.6 \mathrm{~mm})$. Semi-preparative HPLC was performed on reversed-phase columns (YMCpacked $\left.\mathrm{C}_{18}, 5 \mathrm{~mm}, 250 \mathrm{~mm} \times 10 \mathrm{~mm}\right)$. Silica gel $(60-80,200-$
300 mesh, Qingdao Marine Chemical Co. Ltd.), ODS gel (20-45 $\mathrm{mm}$, Fuji Silysia Chemical Co. Ltd.), MCI gel (75-150 mm, Mitsubishi Chemical Co. Ltd.) and Sephadex LH-20 (Merck) were used for column chromatography. TLC was conducted on precoated silica gel $\mathrm{G}$ plates (Qingdao Marine Chemical Co. Ltd.), and the spots were detected by spraying them with $5 \%$ $\mathrm{H}_{2} \mathrm{SO}_{4}$ in EtOH followed by heating.

\subsection{Plant material}

The artificial hole-induced agarwood of A. sinensis was harvested in November 2012 in the Xishuangbanna Dai autonomous prefecture of Yunnan province after four years of formation. The identification of the original plant as Aquilaria sinensis (Lour.) Gilg (Thymelaeaceae) was performed by Dr Jun Wang (Institute of Tropical Bioscience and Biotechnology, Chinese Academy of Tropical Agricultural Science). The voucher specimen (No. 20121108) was deposited at the Institute of Tropical Bioscience and Biotechnology, Chinese Academy of Tropical Agricultural Science, Haikou, China.

\subsection{Extraction and isolation}

The artificial hole-induced agarwood of A. sinensis $(4.7 \mathrm{~kg}$, airdried) was exhaustively extracted by refluxing with $95 \% \mathrm{EtOH}$ $(5 \mathrm{~L} \times 3)$. The EtOH extract $(510.0 \mathrm{~g})$ was dissolved in $\mathrm{H}_{2} \mathrm{O}(2.5$ $\mathrm{L})$ and successively extracted by EtOAc $(2.5 \mathrm{~L} \times 3)$ and $n-\mathrm{BuOH}$ $(2.5 \mathrm{~L} \times 3)$. Subsequently, the EtOAc extract $(310.0 \mathrm{~g})$ was subjected to vacuum-liquid chromatography (VLC) using silica gel by employing a gradient of $\mathrm{CHCl}_{3} / \mathrm{MeOH}(\mathrm{v} / \mathrm{v}, 1: 0,50: 1,25: 1$, $15: 1,10: 1,5: 1,2: 1,1: 1,0: 1,8.0 \mathrm{~L}$ of each) to obtain nine fractions (Fr.1-9).

Fr.5 and Fr.6 were found to be rich in biphenylethylchromone analogues according to their chromogenic reactions on TLC, UV absorptions, and UPLC-MS data analysis. Thus, a combined fraction (89.6 g) of Fr.5 and Fr.6 was purified using the MCI column by eluting with $\mathrm{MeOH}$ to remove pigments, and the residue was subjected to vacuum-liquid chromatography (VLC) and eluted with a stepwise gradient of petroleum ether (PE)/acetone (v/v, $2: 1,1: 1,1: 5,1: 10,1: 20)$ to obtain six subfractions (Fr.A-F). Fr.D (31.4 g) was subjected to Sephadex LH-20 column $(10 \times 120 \mathrm{~cm})$ and eluted with $\mathrm{CHCl}_{3} /$ $\mathrm{MeOH}(\mathrm{v} / \mathrm{v}, 1: 1)$ to give three fractions (Fr.D-1-3). Fr.D-2 (8.1 g) was applied to an ODS gel column and eluted with $\mathrm{MeOH}-\mathrm{H}_{2} \mathrm{O}$ $(\mathrm{v} / \mathrm{v}, 3: 7,2: 3,1: 1,11: 9,3: 2,13: 7,7: 3,4: 1,9: 1,1: 0)$ to give nine fractions (Fr.D-2-1-9).

Fr.D-2-4 (642.8 mg) was eluted with a gradient of $\mathrm{CHCl}_{3} /$ $\mathrm{MeOH}(\mathrm{v} / \mathrm{v}, 35: 1,30: 1,25: 1)$ using silica gel to obtain six fractions (Fr.D-2-4-1-6). The following semi-preparative HPLC separation on $\mathrm{C}_{18}$ column $\left(\mathrm{CH}_{3} \mathrm{CN} / \mathrm{H}_{2} \mathrm{O}\right.$, v/v 25 : 75 as eluent;

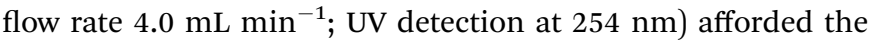
pure compounds $6\left(t_{\mathrm{R}} 21.5 \mathrm{~min}, 25.6 \mathrm{mg}\right)$ and $7\left(t_{\mathrm{R}} 24.1 \mathrm{~min}\right.$, $34.3 \mathrm{mg})$. Fr.D-2-4-3 (22.4 mg) was separated by a silica gel column with $\mathrm{CHCl}_{3} /$ acetone/ $\mathrm{MeOH}(\mathrm{v} / \mathrm{v} / \mathrm{v}, 15: 1: 0.1)$ as the eluent to furnish three fractions (Fr.D-2-4-3-1-3). Fr.D-2-4-3-1 (19.7 mg) was further purified by semi-preparative HPLC on a $\mathrm{C}_{18}$ column $\left(\mathrm{CH}_{3} \mathrm{CN} / \mathrm{H}_{2} \mathrm{O}, \mathrm{v} / \mathrm{v} 25: 75\right.$ as eluent; flow rate 4.0 $\mathrm{mL} \min ^{-1}$; UV detection at $\left.254 \mathrm{~nm}\right)$ to afford compound $8\left(t_{\mathrm{R}}\right.$ 
$17.7 \mathrm{~min}, 0.7 \mathrm{mg}$ ). Fr.D-2-4-5 (95.0 mg) was eluted with a gradient of PE/EtOAc (v/v, $1: 2,1: 8)$ using silica gel to obtain two fractions (Fr.D-2-4-5-1-2). Fr.D-2-4-5-1 (47.4 mg) was followed up by semi-preparative HPLC on a $\mathrm{C}_{18}$ column $\left(\mathrm{CH}_{3} \mathrm{CN} /\right.$

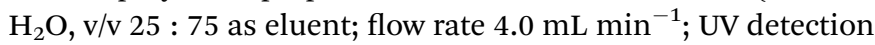
at $254 \mathrm{~nm})$ to give compounds $1\left(t_{\mathrm{R}} 19.3 \mathrm{~min}, 11.7 \mathrm{mg}\right)$ and $2\left(t_{\mathrm{R}}\right.$ $21.7 \mathrm{~min}, 10.6 \mathrm{mg})$.

Fr.D-2-5 (696.4 mg) was separated using a silica gel column with $\mathrm{CHCl}_{3} / \mathrm{MeOH}(\mathrm{v} / \mathrm{v}, 25: 1)$ as the eluent to give seven fractions (Fr.D-2-5-1-7). Fr.D-2-5-3 (187.2 mg) was subjected to a silica gel column eluting with a stepwise gradient of $\mathrm{CHCl}_{3}$ / acetone $/ \mathrm{MeOH}(\mathrm{v} / \mathrm{v} / \mathrm{v}, 5: 1: 0.15,5: 1: 0.2,2: 1: 0.2,2: 1: 2)$ to afford five fractions (Fr.D-2-5-3-1-5). Fr.D-2-5-3-2 (50.1 mg) was separated on a Sephadex LH-20 column by eluting with $\mathrm{CHCl}_{3}$ / $\mathrm{MeOH}(\mathrm{v} / \mathrm{v}, 1: 1)$ and then purified by semi-preparative HPLC on $\mathrm{a}_{18}$ column $\left(\mathrm{MeOH} / \mathrm{H}_{2} \mathrm{O}, \mathrm{v} / \mathrm{v} 55: 45\right.$ as eluent; flow rate 4.0 $\mathrm{mL} \min ^{-1}$; UV detection at $\left.254 \mathrm{~nm}\right)$ to afford compound $5\left(t_{\mathrm{R}}\right.$ $11.9 \mathrm{~min}, 2.0 \mathrm{mg})$. Fr.D-2-5-6 (132.3 mg) was separated using a Sephadex LH-20 column by eluting with $\mathrm{CHCl}_{3} / \mathrm{MeOH}(\mathrm{v} / \mathrm{v}$, $1: 1)$ to afford two fractions (Fr.D-2-5-6-1-2). Fr.D-2-5-6-1 (69.5 $\mathrm{mg}$ ) was chromatographed on a silica gel column with $\mathrm{CHCl}_{3}$ / acetone $/ \mathrm{MeOH}(\mathrm{v} / \mathrm{v} / \mathrm{v}, 2: 1: 0.2)$ as the eluent to give four fractions (Fr.D-2-5-6-1-1-4), and then, Fr.D-2-5-6-1-2 (19.7 mg) was followed up by semi-preparative HPLC on a $\mathrm{C}_{18}$ column $\left(\mathrm{CH}_{3} \mathrm{CN} / \mathrm{H}_{2} \mathrm{O}\right.$, v/v 25 : 75 as eluent; flow rate $4.0 \mathrm{~mL} \mathrm{~min}^{-1}$; UV detection at $254 \mathrm{~nm})$ to give compounds $4\left(t_{\mathrm{R}} 10.0 \mathrm{~min}, 1.0 \mathrm{mg}\right)$ and $11\left(t_{\mathrm{R}} 26.0 \mathrm{~min}, 2.4 \mathrm{mg}\right)$.

Fr.D-2-7 (1.2 g) was separated using a silica gel column with a stepwise gradient of $\mathrm{CHCl}_{3} / \mathrm{MeOH}(\mathrm{v} / \mathrm{v}, 50: 1,30: 1,25: 1$, $20: 1$ ) as the eluent to give nine fractions (Fr.D-2-7-1-9). Fr.D-27-2 (114.8 mg) was chromatographed on a silica gel column with $\mathrm{CHCl}_{3} /$ acetone/ $\mathrm{MeOH}(\mathrm{v} / \mathrm{v} / \mathrm{v}, 10: 1: 0.1)$ as the eluent to give three fractions (Fr.D-2-7-2-1-3), and then, Fr.D-2-7-2-3 (85.1 mg) was further purified by silica gel with $\mathrm{CHCl}_{3} /$ acetone/ $\mathrm{MeOH}(\mathrm{v} /$ $\mathrm{v} / \mathrm{v}, 14: 1: 0.1$ ) as the eluent to obtain three fractions (Fr.D-2-72-3-1-3). Furthermore, Fr.D-2-7-2-3-2 (33.4 mg) was purified by semi-preparative HPLC separation on an ODS column $\left(\mathrm{CH}_{3} \mathrm{CN} /\right.$ $\mathrm{H}_{2} \mathrm{O}, \mathrm{v} / \mathrm{v} 32: 68$ as eluent; flow rate $4.0 \mathrm{~mL} \mathrm{~min}^{-1}$; UV detection at $254 \mathrm{~nm})$ to obtain compound $9\left(t_{\mathrm{R}} 15.4 \mathrm{~min}, 1.7 \mathrm{mg}\right)$. Fr.D-2-7$4(210.0 \mathrm{mg})$ was chromatographed on a silica gel column with $\mathrm{CHCl}_{3} /$ acetone/MeOH (v/v/v, $\left.10: 1: 0.1\right)$ as the eluent to give six fractions (Fr.D-2-7-4-1-6). Fr.D-2-7-4-5 (68.1 mg) was purified by semi-preparative HPLC separation on a $\mathrm{C}_{18}$ column $\left(\mathrm{CH}_{3} \mathrm{CN} /\right.$ $\mathrm{H}_{2} \mathrm{O}, \mathrm{v} / \mathrm{v} 32: 68$ as the eluent; flow rate $4.0 \mathrm{~mL} \mathrm{~min}^{-1}$; UV detection at $254 \mathrm{~nm})$ to obtain compound $10\left(t_{\mathrm{R}} 18.5 \mathrm{~min}, 1.2\right.$ $\mathrm{mg})$.

Compound $3\left(t_{\mathrm{R}} 16.3 \mathrm{~min}, 4.3 \mathrm{mg}\right)$ was isolated from the $n$ $\mathrm{BuOH}$ extract following the same procedures. The purities of the above compounds were analyzed by HPLC.

Aquilasinenone A (1). Yellow oil; $[\alpha]_{\mathrm{D}}^{25}=+107.5$ (c 0.04, $\mathrm{MeOH}) ; \mathrm{UV}(\mathrm{MeOH}) \lambda_{\max }(\log \varepsilon) 231$ (4.56), 252 (4.34), 280 (4.20), 316 (3.99) nm; IR (KBr) $\nu_{\max } 3361,2934,2834,1631,1594,1470$, 1374, 1266, 1026, $856 \mathrm{~cm}^{-1} ;{ }^{1} \mathrm{H}$ and ${ }^{13} \mathrm{C}$ NMR data: Tables 1 and 2; HRESIMS $m / z 711.2057[\mathrm{M}+\mathrm{Na}]^{+}$(calcd for $\mathrm{C}_{37} \mathrm{H}_{36} \mathrm{NaO}_{13}$, 711.2048).

Aquilasinenone B (2). Colorless oil; $[\alpha]_{\mathrm{D}}^{25}=+78.7$ (c 0.10, $\mathrm{MeOH}) ; \mathrm{UV}(\mathrm{MeOH}) \lambda_{\max }(\log \varepsilon) 231$ (4.69), 252 (4.49), 280 (4.36),
318 (3.99) nm; IR (KBr) $\nu_{\max } 3357,2929,2834,1631,1590,1470$, 1378, 1212, 1026, $856 \mathrm{~cm}^{-1} ;{ }^{1} \mathrm{H}$ and ${ }^{13} \mathrm{C}$ NMR data: Tables 1 and 2; HRESIMS $m / z 711.2121[\mathrm{M}+\mathrm{Na}]^{+}$(calcd for $\mathrm{C}_{37} \mathrm{H}_{36} \mathrm{NaO}_{13}$, 711.2048).

Aquilasinenone C (3). Yellow oil; $[\alpha]_{\mathrm{D}}^{20}=-30.6$ (c 0.08, $\mathrm{MeOH}) ; \mathrm{UV}(\mathrm{MeOH}) \lambda_{\max }(\log \varepsilon) 231$ (4.54), 253 (4.39), 280 (4.23), 322 (2.98) nm; IR (KBr) $\nu_{\max } 3388,3207,2954,1644,1515,1448$, 1275, 1275, 1024, 762, $673 \mathrm{~cm}^{-1} ;{ }^{1} \mathrm{H}$ and ${ }^{13} \mathrm{C}$ NMR data: Tables 1 and 2; HRESIMS $m / z 697.1884[\mathrm{M}+\mathrm{Na}]^{+}$(calcd for $\mathrm{C}_{36} \mathrm{H}_{34} \mathrm{NaO}_{13}$, 697.1892).

Aquilasinenone D (4). Colorless oil; $[\alpha]_{\mathrm{D}}^{20}=-25.3(c \quad 0.08$, $\mathrm{MeOH}) ; \mathrm{UV}(\mathrm{MeOH}) \lambda_{\max }(\log \varepsilon) 224$ (4.32), 256 (3.88), 278 (3.78), 314 (3.41) nm; IR (KBr) $\nu_{\max } 3331,2922,1635,1600,1511,1470$, 1431, 1383, 1211, 1179, $1078 \mathrm{~cm}^{-1} ;{ }^{1} \mathrm{H}$ and ${ }^{13} \mathrm{C}$ NMR data: Tables 1 and 2; HRESIMS $m / z$ 695.2095 $[\mathrm{M}+\mathrm{Na}]^{+}$(calcd for $\left.\mathrm{C}_{37} \mathrm{H}_{36} \mathrm{NaO}_{12}, 695.2099\right)$.

Aquilasinenone E (5). Colorless oil; $[\alpha]_{\mathrm{D}}^{20}=-46.2(c$ 0.08, $\mathrm{MeOH}) ; \mathrm{UV}(\mathrm{MeOH}) \lambda_{\max }(\log \varepsilon) 231$ (4.78), 252 (4.66), 316 (4.26) nm; IR (KBr) $\nu_{\max } 3447,3210,2330,1645,1510,1464$, 1432, 1392, 1226, 1181, 1079, $1031 \mathrm{~cm}^{-1} ;{ }^{1} \mathrm{H}$ and ${ }^{13} \mathrm{C}$ NMR data: Tables 3 and 4; HRESIMS $m / z$ 695.2108 $[\mathrm{M}+\mathrm{Na}]^{+}$(calcd for $\left.\mathrm{C}_{37} \mathrm{H}_{36} \mathrm{NaO}_{12}, 695.2099\right)$.

Aquilasinenone $\mathbf{F}$ (6). Yellow oil; $[\alpha]_{\mathrm{D}}^{25}=+30.6$ (c 0.06, $\mathrm{MeOH})$; UV (MeOH) $\lambda_{\max }(\log \varepsilon) 231$ (4.96), 252 (4.74), 280 (4.60), 318 (4.39) nm; IR (KBr) $\nu_{\max } 3365,2934,1635,1590,1470,1378$, 1212, 1034, $810 \mathrm{~cm}^{-1} ;{ }^{1} \mathrm{H}$ and ${ }^{13} \mathrm{C}$ NMR data: Tables 3 and 4; HRESIMS $m / z 711.2062[\mathrm{M}+\mathrm{Na}]^{+}$(calcd for $\mathrm{C}_{37} \mathrm{H}_{36} \mathrm{NaO}_{13}$, 711.2048).

Aquilasinenone $\mathbf{G}(7)$. Colorless oil; $[\alpha]_{\mathrm{D}}^{25}=+53.3(c \quad 0.09$, $\mathrm{MeOH})$; UV (MeOH) $\lambda_{\max }(\log \varepsilon) 231$ (4.71), 252 (4.37), 280 (4.22), 316 (4.02) nm; IR (KBr) $\nu_{\max } 3363,2921,1631,1586,1428,1378$, 1212, 1026, $852 \mathrm{~cm}^{-1} ;{ }^{1} \mathrm{H}$ and ${ }^{13} \mathrm{C}$ NMR data: Tables 3 and 4; HRESIMS $m / z$ 711.2121 $[\mathrm{M}+\mathrm{Na}]^{+}$(calcd for $\mathrm{C}_{37} \mathrm{H}_{36} \mathrm{NaO}_{13}$, 711.2048).

Aquilasinenone $\mathbf{H}$ (8). Colorless oil; $[\alpha]_{\mathrm{D}}^{20}=-46.0(c 0.05$, $\mathrm{MeOH})$; UV (MeOH) $\lambda_{\max }(\log \varepsilon) 228$ (4.17), 254 (3.85), 280 (3.73), 314 (3.45) nm; IR (KBr) $\nu_{\max } 3441,2921,1600,1515,1470,1383$, 1270, 1210, $11123 \mathrm{~cm}^{-1} ;{ }^{1} \mathrm{H}$ and ${ }^{13} \mathrm{C}$ NMR data: Tables 3 and 4; HRESIMS: $m / z 711.2046[\mathrm{M}+\mathrm{Na}]^{+}$(calcd for $\mathrm{C}_{37} \mathrm{H}_{36} \mathrm{NaO}_{13}$ 711.2048).

Aquilasinenone I (9). Yellow oil; $[\alpha]_{\mathrm{D}}^{20}=+10.3(c 0.11, \mathrm{MeOH})$; UV (MeOH) $\lambda_{\max }(\log \varepsilon) 231$ (4.45), 253 (4.25), 278 (4.09), 316 (3.92) nm; IR (KBr) $\nu_{\max } 3448,2929,1642,1508,1388$, $1204 \mathrm{~cm}^{-1} ;{ }^{1} \mathrm{H}$ and ${ }^{13} \mathrm{C}$ NMR data: Tables 5 and 6 ; HRESIMS $\mathrm{m} / \mathrm{z}$ $671.2145[\mathrm{M}-\mathrm{H}]^{-}$(calcd for $\mathrm{C}_{37} \mathrm{H}_{35} \mathrm{O}_{12}, 671.2134$ ).

Aquilasinenone J (10). Yellow oil; $[\alpha]_{\mathrm{D}}^{25}=-45.0$ (c 0.04, $\mathrm{MeOH}) ; \mathrm{UV}(\mathrm{MeOH}) \lambda_{\max }(\log \varepsilon) 231$ (4.31), 252 (4.17), 280 (3.86) nm; IR (KBr) $\nu_{\max } 3390,2921,1656,1511,1478,1374$, 1275, 1022, $839 \mathrm{~cm}^{-1} ;{ }^{1} \mathrm{H}$ and ${ }^{13} \mathrm{C}$ NMR data: Tables 5 and 6; HRESIMS $m / z$ 635.1909 $[\mathrm{M}+\mathrm{Na}]^{+}$(calcd for $\mathrm{C}_{35} \mathrm{H}_{32} \mathrm{NaO}_{10}$, 635.1888).

Aquilasinenone K (11). Yellow oil; $[\alpha]_{\mathrm{D}}^{20}=-88.9(c \quad 0.07$, $\mathrm{MeOH}) ; \mathrm{UV}(\mathrm{MeOH}) \lambda_{\max }(\log \varepsilon) 230$ (4.60), 280 (4.24), 318 (4.05) nm; IR (KBr) $\nu_{\max } 3413,2930,1629,1513,1438,1390$, 1269, 1131, 1085, $1026 \mathrm{~cm}^{-1} ;{ }^{1} \mathrm{H}$ and ${ }^{13} \mathrm{C}$ NMR data: Tables 5 and 6; HRESIMS $m / z 711.2106[\mathrm{M}+\mathrm{Na}]^{+}$(calcd for $\mathrm{C}_{37} \mathrm{H}_{36} \mathrm{NaO}_{13}$, 711.2048). 


\subsection{Bioassay for AChE inhibitory activity}

Compounds 1-11, each dissolved in DMSO, were tested for AChE inhibitory activity using a modified Ellman's colorimetric method. ${ }^{23}$ Briefly, $200 \mu \mathrm{L}$ reaction mixture containing phosphate buffer ( $\mathrm{pH} 8.0$ ), $50 \mu \mathrm{g} \mathrm{mL}{ }^{-1}$ test compound, and $0.02 \mathrm{U}$ $\mathrm{mL}^{-1}$ acetylcholinesterase was incubated for $20 \mathrm{~min}$ at $30{ }^{\circ} \mathrm{C}$. Afterward, $20 \mu \mathrm{L}$ of 5,5'-dithio-bis-(2-nitrobenzoic) acid (DTNB, Ellman's reagent) $\left(2.48 \mathrm{mg} \mathrm{mL}^{-1}\right)$ and $20 \mu \mathrm{L} S$-acetylthiocholine iodide $\left(1.81 \mathrm{mg} \mathrm{mL}^{-1}\right)$ were added, and the hydrolysis of acetylthiocholine was monitored at $405 \mathrm{~nm}$ for one hour. Tacrine (Sigma-Aldrich 99\%) with a final concentration of $0.08 \mu \mathrm{g} \mathrm{mL}^{-1}$ served as the positive control, and DMSO with a final concentration of $0.1 \%$ served as the negative control. The percentage of inhibition was calculated by the equation: \% inhibition $=(E-$ $S) / E \times 100(E$ is the activity of the enzyme without test compounds, and $S$ is the activity of the enzyme with test compounds). The reagents for this reaction were purchased from Sigma Chemical. All the reactions were conducted in triplicates. The values are expressed as mean \pm standard deviation (SD).

\section{Conflicts of interest}

The authors declare that they have no conflicts of interest.

\section{Acknowledgements}

The project was financially supported by the Innovative Research Team Grant of the Natural Science Foundation of Hainan Province (2017CXTD020), National Natural Science Foundation of China (31870668), and China Agriculture Research System (CARS-21).

\section{References}

1 R. Naef, Flavour Fragrance J., 2011, 26, 73-89.

2 C. T. Ma, T. Eom, E. Cho, B. Wu, T. R. Kim, K. B. Oh, S. B. Han, S. W. Kwon and J. H. Park, J. Nat. Prod., 2017, 80, 3043-3048.

3 M. Gao, X. M. Han, Y. Sun, H. J. Chen, Y. Yang, Y. Y. Liu, H. Meng, Z. H. Gao, Y. H. Xu, Z. Zhang and J. P. Han, RSC Adv., 2019, 9, 4113-4130.

4 W. L. Mei, W. J. Zuo, D. L. Yang, W. H. Dong and H. F. Dai, Chin. J. Top. Crops, 2013, 34, 2513-2520.
5 H. Q. Chen, J. H. Wei, J. S. Yang, Z. Zhang, Y. Yang, Z. H. Gao, C. Sui and B. Gong, Chem. Biodivers., 2012, 9, 236-250.

6 S. R. Ibrahim and G. A. Mohamed, Nat. Prod. Res., 2015, 29, 1489-1520.

7 K. Iwagoe, T. Konishi, S. Kiyosawa, Y. Shimada, K. Miyahara and T. Kawasaki, Chem. Pharm. Bull., 1986, 34, 4889-4891.

8 K. Iwagoe, S. Kodama, T. Konishi, S. Kiyosawa, Y. Fujiwara and Y. Shimada, Chem. Pharm. Bull., 1987, 35, 4680-4682.

9 K. Iwagoe, T. Kakae, T. Konishi, S. Kiyosawa, Y. Fujiwara and Y. Shimada, Chem. Pharm. Bull., 1989, 37, 124-128.

10 T. Konishi, K. Iwagoe, S. Kiyosawa and Y. Fujiwara, Phytochemistry, 1989, 28, 3548-3550.

11 T. Konishi, K. Iwagoe, S. Kiyosawa and Y. Fujiwara, Chem. Pharm. Bull., 1991, 39, 1869-1870.

12 H. X. Huo, Z. X. Zhu, Y. L. Song, S. P. Shi, J. Sun, Y. F. Zhao, J. Zheng, J. K. Zjawiony, P. F. Tu and J. Li, J. Nat. Prod., 2017, 81, 543-553.

13 P. Xiang, W. L. Mei, H. Q. Chen, F. D. Kong, H. Wang, G. Liao, L. M. Zhou and H. F. Dai, Fitoterapia, 2017, 120, 61-66.

14 Y. Yang, W. L. Mei, F. D. Kong, H. Q. Chen, W. Li, Z. B. Chen and H. F. Dai, Fitoterapia, 2017, 119, 20-37.

15 Y. Yang, H. Q. Chen, F. D. Kong, L. M. Zhou, W. Li, W. H. Dong, Z. B. Chen, W. L. Mei and H. F. Dai, Phytochemistry, 2018, 145, 207-213.

16 H. X. Huo, Y. F. Gu, Z. X. Zhu, Y. F. Zhang, X. N. Chen, P. W. Guan, S. P. Shi, Y. L. Song, Y. F. Zhao, P. F. Tu and J. Li, Phytochemistry, 2019, 158, 46-55.

17 W. Li, C. H. Cai, Z. K. Guo, H. Wang, W. J. Zuo, W. H. Dong, W. L. Mei and H. F. Dai, Fitoterapia, 2015, 100, 44-49.

18 W. Li, C. H. Cai, W. H. Dong, Z. K. Guo, H. Wang, W. L. Mei and H. F. Dai, Fitoterapia, 2014, 98, 117-123.

19 G. Liao, W. L. Mei, W. H. Dong, W. Li, H. Wang, F. D. Kong, C. J. Gai, X. Q. Song and H. F. Dai, Fitoterapia, 2016, 110, 3843.

20 G. Liao, W. L. Mei, F. D. Kong, W. Li, J. Z. Yuan and H. F. Dai, Phytochemistry, 2017, 139, 98-108.

21 D. Chen, Z. R. Xu, X. Y. Chai, K. W. Zeng, Y. X. Jia, D. Bi, Z. Z. Ma and P. F. Tu, Eur. J. Org. Chem., 2012, 10, 5389-5397.

22 B. Wu, S. W. Kwon, G. S. Hwang and J. H. Park, Helv. Chim. Acta, 2012, 95, 1657-1665.

23 G. L. Ellman, K. D. Courtney, A. J. Valentino and R. M. Featherstone, Biochem. Pharmacol., 1961, 7, 88-90. 